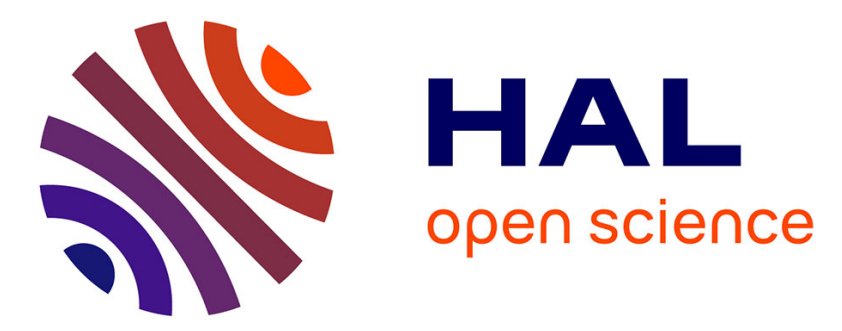

\title{
Constraining the Deep Origin of Parasitic Flatworms and Host-Interactions with Fossil Evidence
}

Kenneth de Baets, Paula Dentzien-Dias, Ieva Upeniece, Olivier Verneau, Philip C.J. Donoghue

\section{- To cite this version:}

Kenneth de Baets, Paula Dentzien-Dias, Ieva Upeniece, Olivier Verneau, Philip C.J. Donoghue. Constraining the Deep Origin of Parasitic Flatworms and Host-Interactions with Fossil Evidence. Advances in Parasitology, 2015, Fossil Parasites, 90, pp.93-135. 10.1016/bs.apar.2015.06.002 . hal-01257074

\section{HAL Id: hal-01257074 \\ https://hal-univ-perp.archives-ouvertes.fr/hal-01257074}

Submitted on 25 Jan 2022

HAL is a multi-disciplinary open access archive for the deposit and dissemination of scientific research documents, whether they are published or not. The documents may come from teaching and research institutions in France or abroad, or from public or private research centers.
L'archive ouverte pluridisciplinaire HAL, est destinée au dépôt et à la diffusion de documents scientifiques de niveau recherche, publiés ou non, émanant des établissements d'enseignement et de recherche français ou étrangers, des laboratoires publics ou privés.

\section{(ㅇ)(1) $\$$}

Distributed under a Creative Commons Attribution - NonCommerciall 4.0 International 


\title{
Constraining the Deep Origin of Parasitic Flatworms and Host- Interactions with Fossil Evidence
}

\author{
Kenneth De Baets* ${ }^{* 1}$, Paula Dentzien-Dias ${ }^{\S}$, leva Upeniece ${ }^{\llbracket,}$ \\ Olivier Verneau ${ }^{\|, \# * * *}$, Philip C.J. Donoghue \\ *Geozentrum Nordbayern, Friedrich-Alexander-Universität Erlangen-Nürnberg, Erlangen, Germany \\ ${ }^{\S}$ Núcleo de Oceanografia Geológica, Instituto de Oceanografia, Universidade Federal do Rio Grande, \\ Rio Grande, Brazil \\ TDepartment of Geology, University of Latvia, Riga, Latvia \\ "Centre de Formation et de Recherche sur les Environnements Méditerranéens, University of Perpignan Via \\ Domitia, Perpignan, France \\ ${ }^{\#}$ CNRS, Centre de Formation et de Recherche sur les Environnements Méditerranéens, Perpignan, France \\ $\star \star$ Unit for Environmental Sciences and Management, North-West University, Potchefstroom, South Africa \\ ${ }^{\S}$ S School of Earth Sciences, University of Bristol, Life Science Building, Bristol, UK \\ ${ }^{1}$ Corresponding author: E-mail: kenneth.debaets@fau.de
}

\section{Contents}

1. Introduction

2. Assessment of the Flatworm Fossil Record 4

2.1 Devonian fossil hook circlets 5

2.2 Silurian blister pearls and calcareous concretions in bivalve shells 9

$\begin{array}{ll}2.3 \text { Permo-Carboniferous egg remains in shark coprolites } & 11\end{array}$

2.4 Cretaceous egg remains in terrestrial archosaur coprolites 13

$\begin{array}{ll}2.5 \text { Eocene shell pits in intermediate bivalve hosts } & 14\end{array}$

$\begin{array}{ll}2.6 \text { Eggs remains in a Pleistocene mammal coprolite } & 15\end{array}$

2.7 Holocene evidence for parasitic flatworms from ancient remains $\quad 15$

$\begin{array}{ll}2.8 \text { Free-living flatworms } & 16\end{array}$

3. Interpolating or Extrapolating Extant Parasite-Host Relationships and the 18

Assumption of Parasite-Host Coevolution

4. Molecular Clock Studies 21

5. Conclusions and Future Prospects 27

Acknowledgements $\quad 29$

References $\quad 30$

\section{Abstract}

Novel fossil discoveries have contributed to our understanding of the evolutionary appearance of parasitism in flatworms. Furthermore, genetic analyses with greater coverage have shifted our views on the coevolution of parasitic flatworms and their hosts. The putative record of parasitic flatworms is consistent with extant host 
associations and so can be used to put constraints on the evolutionary origin of the parasites themselves. The future lies in new molecular clock analyses combined with additional discoveries of exceptionally preserved flatworms associated with hosts and coprolites. Besides direct evidence, the host fossil record and biogeography have the potential to constrain their evolutionary history, albeit with caution needed to avoid circularity, and a need for calibrations to be implemented in the most conservative way. This might result in imprecise, but accurate divergence estimates for the evolution of parasitic flatworms.

\section{INTRODUCTION}

Parasitic flatworms (Platyhelminthes: Neodermata) are a highly diverse group containing many parasites of biomedical, veterinary and economic importance (Olson and Tkach, 2005; Littlewood, 2006). Time constraints on the origin and evolution of parasitism in this group are still poorly resolved due to their patchy and largely overlooked fossil record (Littlewood and Donovan, 2003; Littlewood, 2006). The fossil record of parasitic flatworms is often disregarded by parasitologists (Combes, 2001; Littlewood, 2006; Verneau et al., 2009a; Badets et al., 2011) and evolutionary (paleo)biologists (Labandeira, 2002; Erwin et al., 2011; Wey-Fabrizius et al., 2013) alike. Most parasitologists have therefore focused on extrapolating or interpolating extant parasite-host associations to infer information on the evolution history of parasitic flatworms (Llewellyn, 1987; Brooks, 1989; Brooks and McLennan, 1993; Boeger and Kritsky, 1997; Hoberg, 1999; Hoberg et al., 1999; Littlewood et al., 1999a). Nevertheless, the last two decades have seen several new fossil discoveries, which have extended the record from certain lineages of parasitic flatworms deeper into the Cenozoic (Jouy-Avantin et al., 1999; Todd and Harper, 2011) or from the Cenozoic to the Mesozoic (Poinar and Boucot, 2006) or even the Paleozoic (Upeniece, 2001, 2011; Dentzien-Dias et al., 2013).

Furthermore, molecular analyses have considerably shifted our views on flatworm phylogeny (Lockyer et al., 2003a; Olson and Tkach, 2005; Littlewood, 2008; Perkins et al., 2010; Laumer and Giribet, 2014) with implications for older hypotheses of parasite-host coevolution. Due to the patchy fossil record, establishing the phylogeny of flatworms is particularly important for establishing a timeline for the group. Traditionally, Monogenea (ectoparasitic with simple life cycles) and Cestoda (endoparasitic with complex, trophically transmitted, life cycles) were often grouped based on morphological similarities of their larval stages (Bychowsky, 1937; Brooks, 
1989), sometimes referred to as the cercomer theory (Lockyer et al., 2003a). However, most recent molecular-based analyses (Mollaret et al., 1997; Lockyer et al., 2003a; Park et al., 2007; Perkins et al., 2010; Wey-Fabrizius et al., 2013; Hahn et al., 2014; Egger et al., 2015) and those including alternative data such as microRNAs (Fromm et al., 2013) indicate a sister-group relationship between cestodes and trematodes (rather than between Monogenea and Cestoda) with one possible exception (Laumer and Giribet, 2014; Laumer et al., 2015), although no clear morphological characters support this arrangement. Interestingly, the monophyly of Monogenea i.e. the sister-group relationship between Monopisthocotylea and Polyopisthocotylea based on morphological data (Boeger and Kritsky, 2001), is not always supported by molecular phylogenetics (Mollaret et al., 1997; Justine, 1998; Lockyer et al., 2003a) either. Based on recent results employing mitogenomic data, primitive parasitic flatworms (Neodermata) were probably ectoparasitic with a simple life cycle on vertebrates (Park et al., 2007) and engaged in epithelial feeding (Perkins et al., 2010). Subsequently, it has been proposed they added an intermediate host to their life cycle, probably first a crustacean intermediate host in Cestoda and a mollusc intermediate host in Trematoda (Park et al., 2007) before switching to a blood diet (Perkins et al., 2010). This differs from previous hypotheses (Brooks, 1989; Littlewood et al., 1999a), where a sister-group relation between Monogenea and Cestoda, and between these taxa and Trematoda was postulated. This led to two now probably outdated hypotheses of interpreting the life cycle evolution of Neodermata (Park et al., 2007). One hypothesis (Littlewood et al., 1999a) suggested that proto-neodermatan first acquired an endoparasitic association with vertebrates and that independent adoptions of invertebrates by the Trematoda (molluscs) and Cestoda (crustaceans) as well as ectoparasitism in Monogenea were subsequent acquisitions (vertebrate first hypothesis). Another hypothesis (Cribb et al., 2001) suggested that the association of common ancestor of the Trematoda with molluscan hosts was primitive (acquiring its subsequent vertebrate hosts independently), and that the vertebrates were involved in the life cycle of the common ancestor of the Monogenea + Cestoda clade as independent initial hosts apart from that of trematodes, with the crustaceans as subsequent intermediate hosts adopted by the Cestoda groups after the ancestral cestode diverged from the monogeneans (mollusk first hypothesis).

The closest free-living relatives of helminths are also important in constraining divergence times in their evolutionary history (Littlewood et al., 1999b; Near, 2002; Littlewood, 2006). However, the phylogeny of 
free-living flatworms has proven even more problematic (but see Littlewood and Waeschenbach, 2015 for a review of recent advances) and has been further complicated by the fact that some extant forms traditionally included in Platyhelminthes have been excluded from the phylum based on molecular analyses (Jondelius et al., 2002; Telford et al., 2003; Willems et al., 2006; Wallberg et al., 2007; Hejnol et al., 2009) such as the Acoela (Ruiz-Trillo et al., 1999; Mwinyi et al., 2010; Philippe et al., 2011) and Xenoturbella (Bourlat et al., 2003). Furthermore, platyhelminths have often been grouped in the Platyzoa (Cavalier-Smith, 1998) together with various other taxa including Acanthocephala, which have convergently evolved a parasitic lifestyle with larval stages and have been shown to be closely related with free-living Rotifera (Near, 2002; Weber et al., 2013). It remains unclear whether Platyzoa is a clade or an artificial grouping generated by systematic error and long-branch attraction artefacts (Edgecombe et al., 2011; WeyFabrizius et al., 2013; Struck et al., 2014), since subsequent studies have not only disagreed on the membership of the phyla, but also on the relationships within this grouping. This makes new fossil discoveries of parasitic flatworms not only relevant in constraining the evolutionary origin of flatworms, but also that of the Platyzoa as a whole.

Here we review the potential of fossil flatworm evidence with a view to using these data to constrain the timescale for the evolutionary history of this group and outline how they can be used to improve our understanding of the evolutionary radiation of the Neodermata. We consider whether these rare fossil finds are at least consistent with coevolution of parasitic flatworms and their hosts, as well as how fossil finds and other geological evidence in combination with molecular clock methodology can be best used to constrain the temporal framework for the evolution of parasitic flatworms. Such a temporal framework is a key to test evolutionary hypotheses regarding the origin and diversification of parasitism and its coincidence with certain biogeographic events, major environmental changes or key ecological or evolutionary events in the evolution of their hosts.

\section{ASSESSMENT OF THE FLATWORM FOSSIL RECORD}

Fossil evidence for parasitic flatworms can be derived from (1) rare exceptionally preserved body fossils, which can be isolated (Poinar and Boucot, 2006; Dentzien-Dias et al., 2013) or remain associated with their hosts (Upeniece, 2001, 2011) or (2) more commonly occur as characteristic 
traces or skeletal pathologies in their (intermediate) hosts, which have the potential to be traced back in the fossil record (Ruiz and Lindberg, 1989; Ruiz, 1991; Ituarte et al., 2001, 2005; Huntley, 2007; Todd and Harper, 2011; Huntley and Scarponi, 2012; Huntley et al., 2014; Huntley and Scarponi, 2015; Huntley and De Baets, 2015). Parasite body fossils are scarce due to their small size, lack of hard parts and the residence within the host and/or isolation from their hosts (Conway Morris, 1981; Littlewood and Donovan, 2003; De Baets et al., 2011). The rarity of fossilized parasite-host associations and the fact that culprits of traces or pathologies in the skeletons of their hosts are often hard to identify can make it difficult to infer parasite-host associations from the fossil record. Nevertheless, it is the only direct evidence for the presence of such associations in the geological past.

\subsection{Devonian fossil hook circlets}

Circlets of fossil hooks described from the Devonian of Latvia (Upeniece, 1996, 1998, 1999, 2001, 2011) are the oldest potential body fossil evidence for parasitic flatworms. Upeniece $(2001,2011)$ discovered about 77 circlets, which were mostly attached or closely associated with fossil gnathostomes (16 juveniles of the antiarch placoderm Asterolepis ornata; 27 specimens of the acanthodian Lodeacanthus ganjicus: Figures 1(b, c, e, f)). However, one isolated circlet was found close to a specimen of a clam shrimp (Figure 1(g)) and two other circlets were found associated with another crustacean arthropod (Mysidacea: Figure 1(e)), but the hooks are too large to indicate parasitism based on the size of the crustaceans.

The location of these remains in fossils of their vertebrate hosts (Figure 1(b) and (c)) and their similarity to the hooks of parasitic helminths, strongly suggest a parasitic nature (Upeniece, 2011). In acanthodians (L. gaujicus), they are associated with the gill regions, near the fin spines, and in the abdominal region near the scapula (Figure $1(\mathrm{~d})$ and $(\mathrm{f})$ ), while in placoderms $(A$. ornata) their location is not so well determined (see Figure 1(a)). The length of infested fishes varies between 1 and $4 \mathrm{~cm}$ (Figure 1(a) and (d)). Several of them were infested with 2-9 parasites (7 hook circlets can be counted in the specimen figured in Figure 1(b)). Most authors agree that they are the remains of parasitic helminths, although their exact affinity remains the subject of debate (Upeniece, 2001; Littlewood and Donovan, 2003; Upeniece, 2011). These are reminiscent of hooks which are used by Neodermata (Monogenea, Cestoda) and Acanthocephala to attach themselves to their hosts. Differences in morphology and their location on the host body (Upeniece, 2011) might even indicate that they belong to different groups 

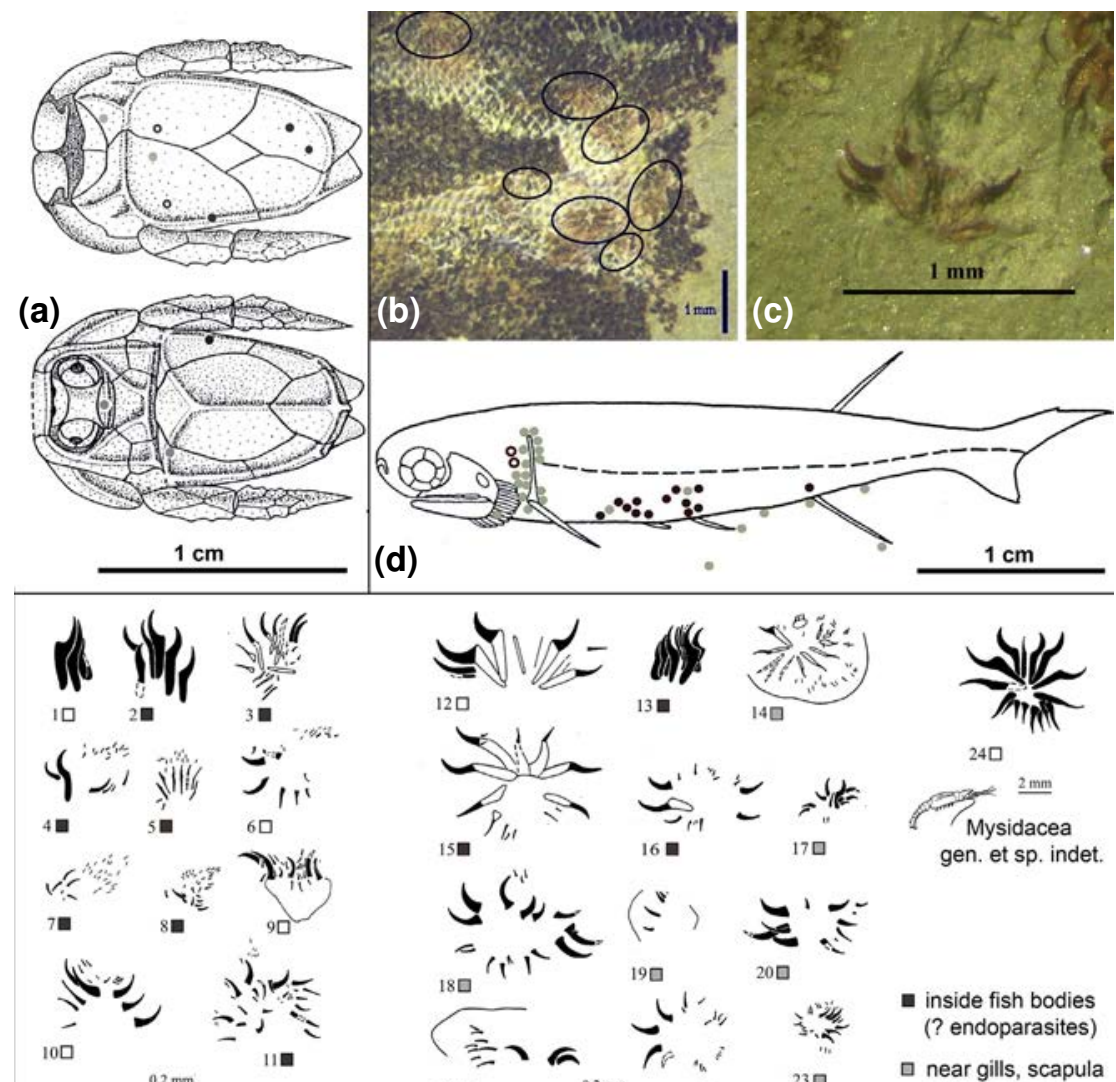

(d)

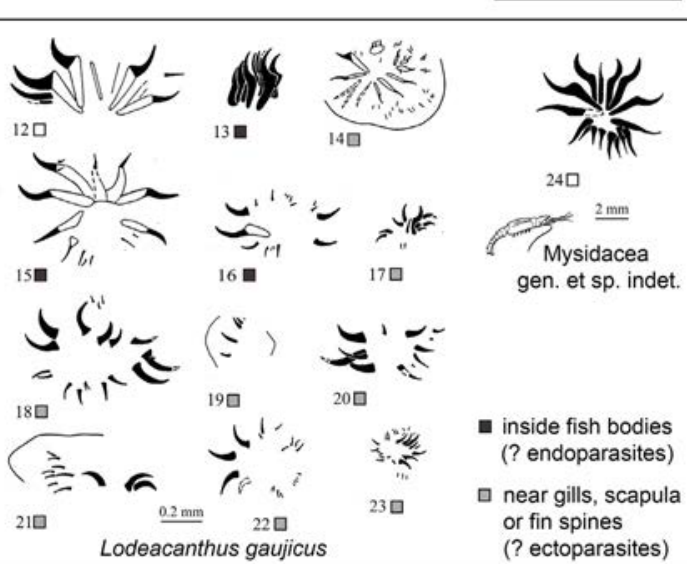

(e) Asterolepis ornata

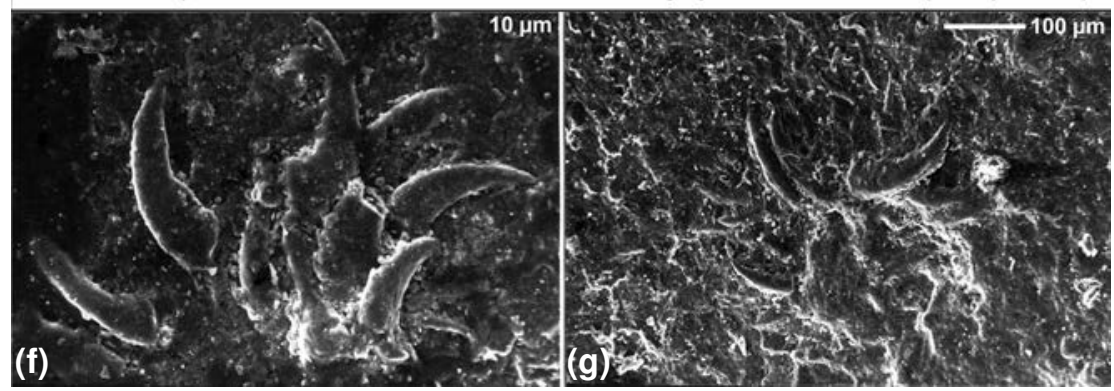

Figure 1 Fossil helminth remains in Middle Devonian gnathostomes (Upeniece, 2001, 2011) (Modified from Upeniece (2011) unless otherwise stated.): (a) Locations where helminth remains were found on juveniles of the placoderm Asterolepis ornata. (b) Multiple fossil circlets of parasitic helminth hooks (marked with ellipses in (a)) found inside the acanthodian Lodeacanthus gaujicus, LDM 270/18c (Upeniece, 2001, PI. 3, Figure 2); (c) Close-up on the hook circlet found associated with L. gaujicus, specimen LDM 270/ 33; (d) Locations where helminth remains were found in juvenile and adults of the 
of parasites (Upeniece, 2001), including ectoparasites (e.g. monogeneans) and endoparasites (e.g. cestodes and acanthocephalans).

The circular arrangement of the bilaterally symmetrically located hooks, traces of cuticular disc as well as the maximum number of 16 hooks, which is characteristic for early divergent monogeneans (Boeger and Kritsky, 1993), indicates that at least some of them represent Monogenea (Combes, 2001; Upeniece, 2011), although the larvae of Cestoda can also have radially arranged chitinous hooks for attachment. The hooks are also considerably larger (length: $0.02-0.40 \mathrm{~mm}$ ) than those of extant flatworms, but this does not necessarily rule out a monogenean affinity. Poulin (2005), for example, could demonstrate an evolutionary trend towards decreasing body size in extant ectoparasitic Monogenea, while this was less clear for derived endoparasitic flatworms (Digenea). Interestingly, Upeniece (2011) observed that small-sized acanthodians possessed small hook systems, while larger acanthodians exhibited the greatest range in size of the hook systems. These might indicate that parasites might have spent all their life in one host, which might further corroborate a similarity to early divergent parasitic flatworms. The lack of fossilized soft body parts, with the exception of traces of the disc outline, further hampers a more precise taxonomic assignment. Upeniece $(1999,2011)$ suggested that at least two morphological groups are presented in both species of fish: hooks with a 'handle' and hooks without a 'handle'. She noticed that the hooks with 'handles' typically occur in the abdominal region of acanthodians and placoderms, suggestive of a close affinity with endoparasites such as Acanthocephala or Cestoda. The elongated tubelike body of acanthocephalans typically possesses a thorny proboscis, which is an anterior retractile organ bearing a large number of hooks (Bush et al., 2001). This holdfast organ is only fully evaginated after death and resembles the 'introvert' of Rotatoria, Priapulida, Kinorhyncha and Nematomorpha larvae (Taraschewski, 2005). Larval forms of Cestoda typically bear hooks, present even in basal extant Cestoda like Gyrocotylidae (Xylander, 2005) and Amphilinidea (typically 10), which can be retained in the adult forms

acanthodian L. gaujicus; (e) Schematic drawing of circlets of fossil hooks (Modified from Upeniece (1999).) found in juveniles of placoderm fish A. ornata (No 1-11), in juveniles and adults of acanthodian L. gaujicus (No 12-23), and in/on crustacean Mysidacea (No 24); (f) Fossil hooks found in juvenile acanthodian body near the scapula (see also Figure 1(e), No. 17), LDM 270/4a; (g) fossil hooks found near a clam shrimp. All specimens derive from the Middle Devonian, Liepa (Lode) pit. Dark grey circles, squares possible endoparasites; Light grey circles, squares - possible ectoparasites. 
such as in Amphilinidea (Rohde, 2005). Derived Cestoda have a specialized attachment device (the scolex) that has a highly variable morphology and may have hooks: Diphyllidea typically possesses a scolex bearing a dorsal and ventral set of apical hooks (Caira and Reyda, 2005), some Cyclophyllidea have a dome-shaped structure at the end of the scolex, the rostellum, which may be armed with hooks arranged in one or more circles (Bush et al., 2001), while others like Trypanorhyncha can have a scolex with four retractable tentacles bearing hooks (Caira and Reyda, 2005). Most authors agree that the fossil circlets of hooks probably belong to platyzoan helminths (Upeniece, 2001, 2011; Poinar, 2003), although we cannot entirely exclude the possibility that they belong to a now-extinct lineage of parasites. A reinvestigation of these attachment structures with particular focus on taphonomy, their composition (element analysis) and the three-dimensional structure using computer tomography can be particularly useful for disentangling phylogenetic affinity as it did for the elements of the now-extinct conodonts (Purnell and Donoghue, 1997; 2005; Goudemand et al., 2011; Murdock et al., 2013). Whatever the exact taxonomic affinity of the parasite hook circlets, they remain the oldest direct evidence for the presence of helminth-gnathostome and helminth-vertebrate association in the fossil record (Boucot and Poinar, 2010).

Age: The finds of the Lode Formation were described initially as Early Frasnian, Upper Devonian (Upeniece, 2001), although most authors now assign this to the Upper Givetian, Middle Devonian (Mark-Kurik et al., 1999; Jurina and Raskatova, 2012; Lukševičs et al., 2012; Mark-Kurik and Põldvere, 2012; Lukševičs et al., 2014). This corresponds with at least 381.9 Ma, the minimum age assigned to the Givetian-Frasnian boundary (382.7 Ma \pm 0.8 Myr: Becker et al., 2012). It is common practice in geological and paleontological studies to use Ma for 'Million years ago', while XX Myr is often used to refer to a duration of XX million years.

Lukševics et al. (2009) attributed various skeletal pathologies from Middle (Givetian) to Upper Devonian (Frasnian, Famennian) gnathostomes to cestode and trematode infestations. However, the characteristics of these (Lukševics et al., 2009) and other pathologies like skin lesions (Petit, 2010; Petit and Khallouf1, 2012) are insufficient to attribute them to particular group of parasites confidently, or even rule out potential other causes. Interestingly, they also overlap temporally with the presence of blister pearls in Devonian ammonoids (Rakociński, 2012), which might also have been caused by parasitic flatworms, although no conclusive evidence for a parasitic flatworm infestation was found (De Baets et al., 2011, 2013, 2015). 


\subsection{Silurian blister pearls and calcareous concretions in bivalve shells}

As (blister) pearls and volcano- to igloo-shaped concretions can be induced by intermediate stages of parasitic flatworms (Götting, 1974, 1979; Lauckner, 1983; Campbell, 1985; Ituarte et al., 2001, 2005), their first occurrence in the Silurian (Kř́rž, 1979; Liljedahl, 1985, 1994; De Baets et al., 2011) might already indicate the presence of derived parasitic flatworms in the Silurian. Pearls and blisters can, however, be caused by a variety of irritants, including other parasites, shell burrowing organisms and inorganic particles (Götting, 1974; Lauckner, 1983). The earliest known fossil blister pearls from the Silurian (Kř́̌ž, 1979; Liljedahl, 1985, 1994) and earliest known free pearls from Triassic (Kutassy, 1937; Conway Morris, 1981; Combes, 2001; Geyer et al., 2005; Rouse, 2005; Boucot and Poinar, 2010) are therefore not characteristic for parasitism unless parasitic remains can be found inside of them (De Baets et al., 2011). This is not straightforward since it has been demonstrated that the remains of soft-bodied helminths can be destroyed during the pearl formation process (Lauckner, 1983). However, other pathologies are believed to be more characteristic for particular lineages of parasitic flatworms such as Gymnophallidae including shell pits (Ruiz and Lindberg, 1989; Ruiz, 1991; Huntley, 2007; Todd and Harper, 2011, Figure 1(e); Huntley and Scarponi, 2012; Huntley et al., 2014; Huntley and Scarponi, 2015; Huntley and De Baets, 2015) and volcano- to igloo-shaped calcareous concretions (Campbell, 1985; Ituarte et al., 2001, 2005; Figure 2(a-c); Huntley and De Baets, 2015). Ituarte et al. (2001, 2005) demonstrated a link between igloo-shaped concretions and gymnophallid digenean flatworms, which these authors traced back to 6400 years in the Holocene. Superficially, similar igloo-shaped concretions have, however, also been reported from the Upper Silurian (Liljedahl, 1985, 1994; Figure 2(d)), but the Paleozoic occurrence of this structure is not consistent with extant host associations of Gymnophallidae, which typically have shorebirds (Charadriiformes) as final hosts (Ching, 1995), although some forms also infest humans as final hosts (Lee and Chai, 2001). The earliest fossils that can be confidently assigned to extant lineages of charadriiform birds are stem-group representative of Alcidae from the Upper Eocene of North America (Mayr, 2011), although older charadriiform-like fossils have been reported from the Lower Eocene of Denmark (Bertelli et al., 2010, 2013). Molecular clock estimates usually place the origin of shorebirds in the Cretaceous (Paton et al., 2003; Baker et al., 2007), although this might be based on the incorrect 

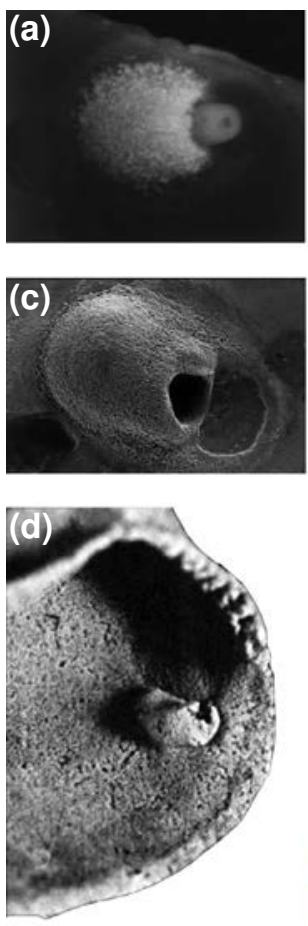
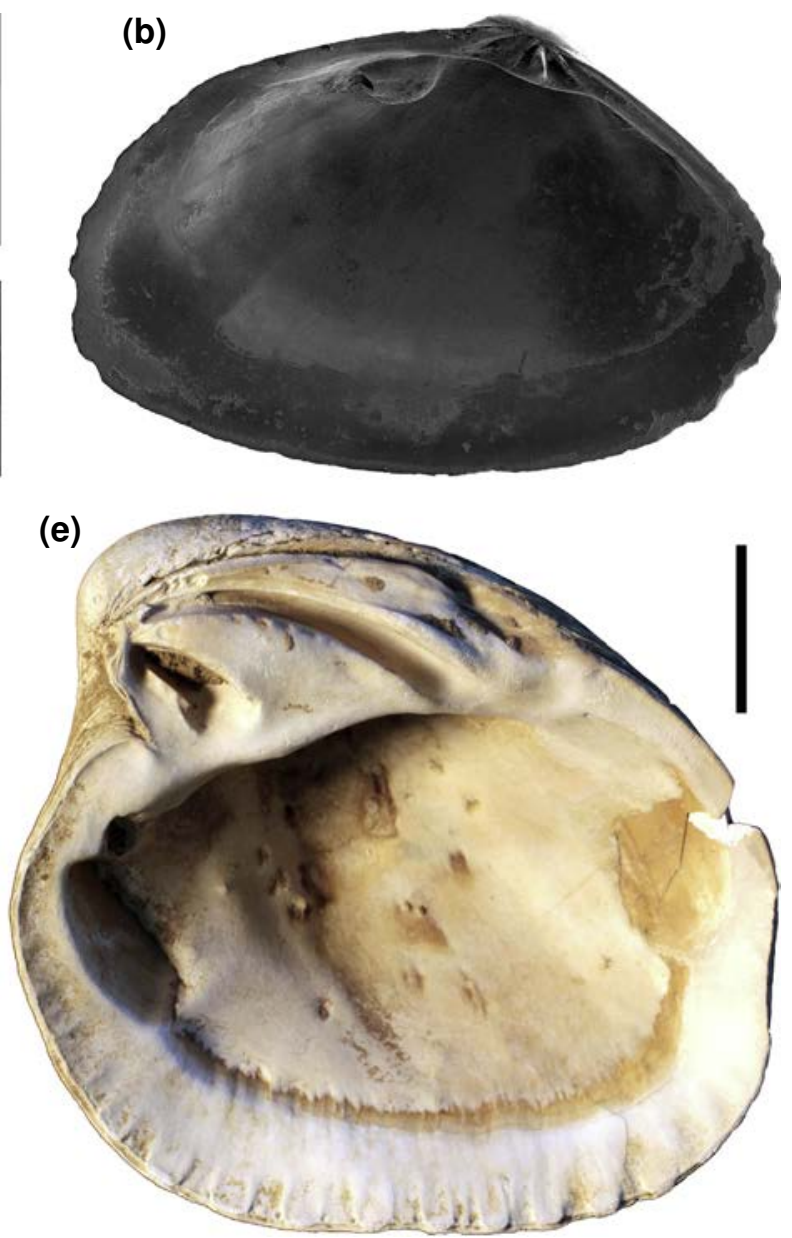

Figure 2 Shell structures (igloo-shaped concretions, shell pits) which have been linked with gymnophallid trematodes (Digenea) in extant and fossil bivalves. (a) Metacercaria lodged in live position into an igloo-shaped calcareous covering of Gaimardia trapesina (MLP 5659) from Beagle Channel in Ushuaia; note the noncalcified area around the anterior end of the larva (photo: Cristian Ituarte; refigured from Ituarte et al. (2005).); (b) Scanning electron micrograph of a left valve of Cyamiomactra sp. from a Holocene sample of Río Varela (Tierra del Fuego) showing a single igloo-shaped covering just below the anterodorsal margin (Photo: Cristián Ituarte; refigured from Ituarte et al. (2005).); (c) Upper view of an igloo-shaped covering in G. trapesina (MLP 5659) from Beagle Channel in Ushuaia showing the non-calcified area in front of the igloo opening (Photo: Cristian Ituarte; refigured from Ituarte et al. (2005).); (d) Igloo-shaped concretion found close to posterior adductor muscle scar in the Silurian bivalve Nuculodonta gotlandica (SGU Type 1030) from the Halla Formation of Gotland (Modified from Liljedahl (1994).); (e) Interior of right valve of Venericor clarendonensis (NHMUK PI TB 14236) from the Eocene (subdivision B2 of the London Clay) with irregular shell deformations and shell pits interpreted to have been produced in response to digenean trematode infestation. Photo courtesy of Jon Todd; compare Todd and Harper (2011). 
placement of fossil taxa (Dyke and Van Tuinen, 2004; Thomas et al., 2004; Mayr, 2011) and/or other methodological artefacts (cf. Ksepka et al., 2014). The appearance of shorebirds in the Cretaceous or Early Paleogene suggests that the Paleozoic structures were probably caused by a different group of parasites or even epizoa (Liljedahl, 1985, 1994) with similar behaviour, although we cannot rule out the possibility that gymnophallids, or closely related (now potentially extinct) taxa or their ancestors, had different life cycles and host associations in the past. Shell pits have so far been traced back only to the Eocene (Ruiz and Lindberg, 1989; Todd and Harper, 2011; Huntley and De Baets, 2015), which is more or less consistent with the presence of gymnophallid-shorebird associations (Figure 2).

Age: The Silurian occurrence of an igloo-shaped concretion was found in the silicified Möllboss 1 fauna from the Halla Formation (previously Halla Beds) of Gotland (Liljedahl, 1985, 1994). Jeppsson et al. (2006) correlated Möllboss 1 with the parvus graptolite biozone and the Ozarkodina bohemica longa conodont subzone 2 as defined by Calner and Jeppsson (2003). The top of the Pristiograptus dubius parvus - Gothographus nassa graptolite biozone has been dated to $428.18 \pm 0.4796 \mathrm{Myr}$, yielded an minimum age of 427.7 Ma (Melchin et al., 2012). This is consistent with $\mathrm{U}-\mathrm{Pb}$ age of $428.45 \pm 0.35$ Myr obtained by Cramer et al. (2012) for the Grötlingbo bentonite at the nearby locality Hörsne 3 , which has been correlated with Möllboss 1 (Jeppsson et al., 2006) and probably accounts for some of the silification of the strata there (Mikael Calner, personal communication 2014).

\subsection{Permo-Carboniferous egg remains in shark coprolites}

The earliest confident record of parasitic flatworms with complex parasite life cycles are eggs attributed to Cestoda from the Rio do Rasto Formation (Dentzien-Dias et al., 2013), which has been assigned to the Middle to Late Permian (Holz et al., 2010). The eggs were obtained from a coprolite (Figure 3(a)), which was isolated from its host and forms part of a set of more than 800 coprolites of different shapes and sizes found in a geographically restricted area (Dentzien-Dias et al., 2012, 2013). It was identified as a shark coprolite by its spiral structure and fossil content (Dentzien-Dias et al., 2012, 2013). The eggs occur in a cluster (Figure 3(b)) and are ovoid, smooth shelled and with a small operculum (polar swelling) suggesting that they are nonerupted eggs (Figure 3(c) and (d)). Most eggs are filled with pyrite and one egg is suggestive of containing a developing larva (Figure 3(c) and (d)). The eggs vary little in size within the cluster, ranging from 145 to $155 \mu \mathrm{m}$ in length and $88-100 \mu \mathrm{m}$ in width. The morphological features 
(a)
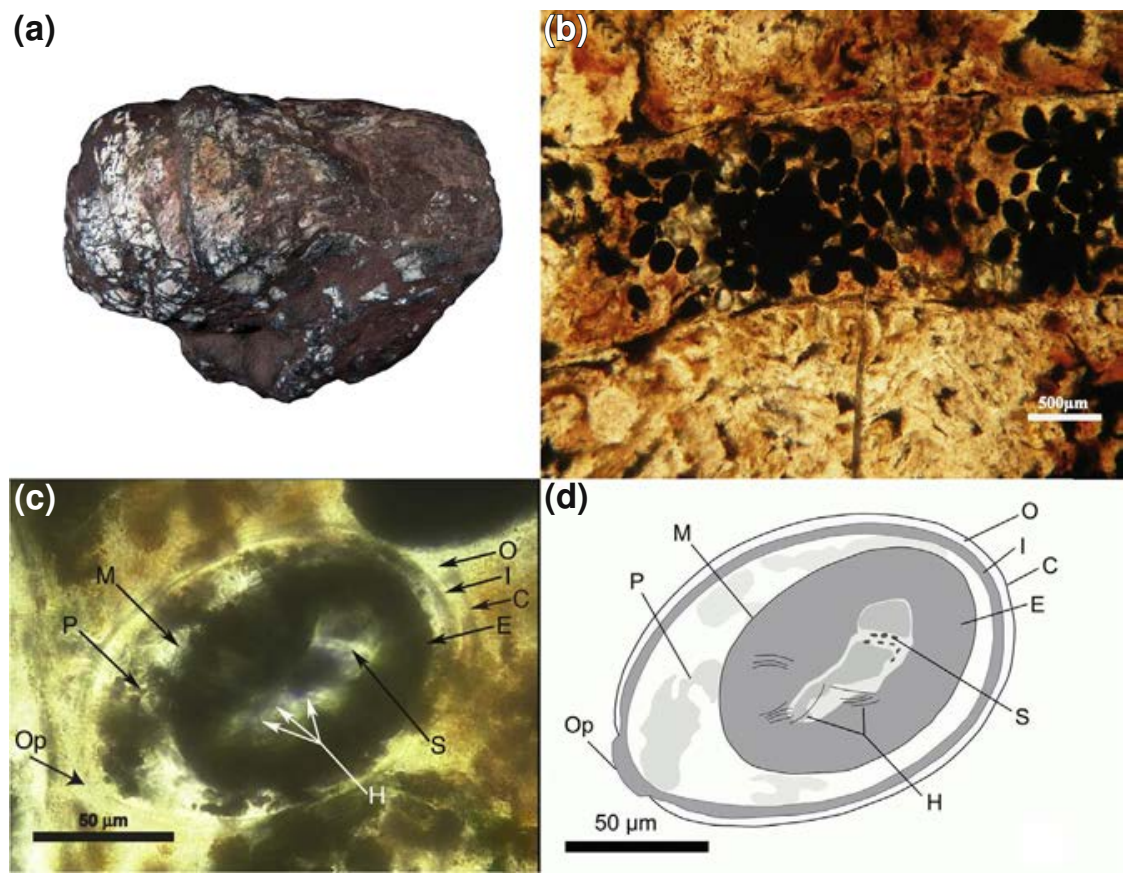

(d)

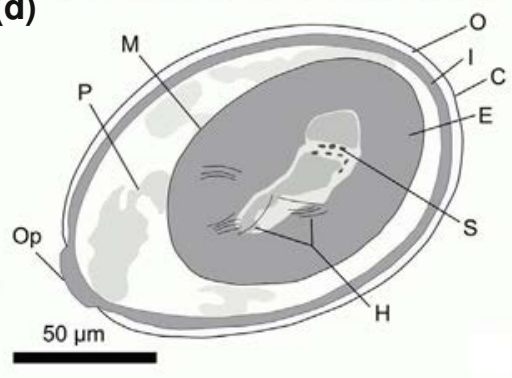

Figure 3 Fossil evidence for the presence of derived parasitic flatworms (Cestoda) in the Middle Permian (Modified from Dentzien-Dias et al. (2013).): (a) Picture of the spiral heteropolar coprolite from the Rio do Rasto Formation, which has yielded the cestode eggs, before destructive thin section analysis; (b) Thin section of the coprolite part containing parasite eggs clustered in; (c) Cestode egg with a developing embryophore. (d) Partial reconstruction of egg in (c) with interpretations of the observed structures. Abbreviations: $\mathrm{C}=$ capsule or shell; $\mathrm{E}=$ embryophore (ochosphere); $\mathrm{H}=$ putative developing hooklets; $\mathrm{I}=$ inner envelope; $\mathrm{M}=$ oncospheral membrane; $\mathrm{O}=$ outer envelope; $\mathrm{P}=$ putative polar thickening; $\mathrm{Op}=$ operculum; $\mathrm{S}=$ somatic cells.

of these eggs (operculum, egg shape and size: Figure 3(c) and (d)) as well as their deposition together in an elongate arrangement (Figure $3(\mathrm{~b})$ ), which is typical of modern tapeworm eggs deposited in mature segments or proglottids, corroborates their cestode affinity.

Age: The coprolite derives from the upper member of the Rio do Rasto Formation, which has also yielded a variety of vertebrate faunas (DentzienDias et al., 2012). The locality is located near Posto Queimado, where vertebrate faunas indicate a Guadalupian (Late Wordian-Capitanian) age (Cisneros et al., 2012; Dias-Da-Silva, 2012). The coprolite should therefore be older than the Guadalupian (Capitanian)-Lopingian (Wuchiapingian) boundary dated to at least 259.4 Ma (259.8 \pm 0.4 Myr: Henderson et al., 2012). 
Older reports of potential cestode eggs (Zangerl and Case, 1976; Combes, 2001) within a Carboniferous coprolite are still controversial (Boucot, 1990; Poinar, 2003; Dentzien-Dias et al., 2013). Strictly speaking, this coprolite should be called a cololite as the fossilized faecal remains were found lodged within its producer (Hunt et al., 2012). Boucot (1990) considered the report as fairly speculative as the urea-rich environment of the dead shark would probably lead to the rapid decomposition of such eggs, but the latest discovery of cestode eggs in a Permian shark coprolite (Dentzien-Dias et al., 2013) illustrate that their interpretation as helminth eggs cannot be excluded. However, further analyses of the morphology and the arrangement of these spherical bodies are necessary to confirm their assignment to cestodes (Zangerl and Case, 1976; Combes, 2001) or other parasitic helminths.

Age: The Cobelodus aculeatus specimen with the putative cestode eggs derives from the Stark Shale, the core black shale member of the Dennis Formation of the Missouri Series, near Fort Calhoun, Nebraska. It was assigned to the Westphalian D by Zangerl and Case (1976) without any information corroborating this assignment. The Missouri series form part of the local Missourian stage, which largely corresponds with the Kasimovian (Falcon-Lang et al., 2011), which also includes the Stark Shale (Rosscoe, 2008; Rosscoe and Barrick, 2013). An age older than the KasimovianGzhelian boundary (303.6 Ma according to the 2012 Geological Timescale: Davydov et al., 2012) can therefore be used as minimum constraint. Pending reinvestigation of this fossil, it could extend range of cestode eggs in shark coprolites by an additional 40 Myr.

\subsection{Cretaceous egg remains in terrestrial archosaur coprolites}

The oldest fossil evidence for Trematoda is an egg which was recovered from an Early Cretaceous isolated terrestrial vertebrate coprolite found near Bernissart in Belgium (Poinar and Boucot, 2006). The producers of these coprolites (and therefore also hosts of the parasites) are still debated (Chin et al., 1998; Baele et al., 2012). Both Bertrand (1903) and Poinar and Boucot (2006) presented arguments that they could have been produced by theropod dinosaurs (as opposed to crocodiles). However, theropod coprolites are rare (Hone and Rauhut, 2010), particularly when compared with coprolites of aquatic vertebrates (Chin, 2002) such as crocodylians in contemporary deposits (Hunt et al., 2012). Their seemingly precise assignment to 'Megalosaurus' dunkeri is therefore questionable, as it is based on the co-occurence of a single metarsal in the same deposits. This metatarsal was originally assigned to $M$. dunkeri 
(now Altispinax dunkeri), but its morphology is only sufficient to assign it to theropods at best (Pascal Godefroid, personal communication 2014). Nevertheless, it remains the oldest evidence for trematodes in terrestrial predatory archosaurs (Poinar and Boucot, 2006).

Age: The fossil-bearing strata are now more precisely dated to be of Late Barremian to Early Aptian age (Yans et al., 2005; Schnyder et al., 2009; Yans et al., 2012), corresponding with the upper part of magnetochron M1n, M0r and the basal part of M0n. This yields an approximate minimum age for these strata of $125.93 \mathrm{Ma}$, the age attributed to the top of magnetochron M0r by Ogg (2012), or a more conservative age of $125.7 \mathrm{Ma}$, the age assigned to the base of the Tethyan Deshayesites deshayesi ammonoid biozone (Schnyder et al., 2009) by Ogg et al. (2012).

\subsection{Eocene shell pits in intermediate bivalve hosts}

The oldest evidence for the presence of Gymnophallidae might lie in the Eocene in the form of characteristic shell pits found in their intermediate bivalve hosts (Ruiz and Lindberg, 1989, Figure 2(e), Todd and Harper, 2011). These characteristic pits have been reported throughout the Cenozoic from the Eocene to the Holocene (Johannessen, 1973; Ruiz and Lindberg, 1989; Ruiz, 1991; Huntley, 2007; Todd and Harper, 2011; Huntley and Scarponi, 2012, 2015; Huntley et al., 2014; Huntley and De Baets, 2015). These pits have been commonly linked with Gymnophallidae (Ruiz and Lindberg, 1989; Todd and Harper, 2011), although superficially similar structures might also be caused by other digenetic trematodes such as Lepocreadiidae (Ituarte et al., 2001; see review by Huntley and De Baets, 2015).

Age: The oldest precisely dated shells (Venericor clarendonensis) with pits derive from subdivision B2 of the London Clay, Eocene (Todd and Harper, 2011). Berggren and Aubry (1996) assigned this unit to upper calcareous nannofossil zone NP11, which corresponds with a minimum age of $53.9 \mathrm{Ma}$ according to the 2012 Geological Timescale (Vandenberghe et al., 2012).

Further support could come from the distribution of volcano-shaped (Campbell, 1985) to igloo-shaped calcareous concretions (Ituarte et al., 2001, 2005), which have been traced back to at least $6240 \pm 70$ years BP in the Holocene (Ituarte et al., 2005). Despite a certain degree of variability in these structures in extant bivalves, they are believed to be characteristic for gymnophallid trematodes (Campbell, 1985; Ituarte et al., 2001, 2005). Studies on pathology have focused on invertebrate intermediate hosts (Ruiz and Lindberg, 1989; Ituarte et al., 2001, 2005; Huntley, 2007; Huntley and Scarponi, 2012; Huntley et al., 2014; Huntley and De Baets, 
2015), although some pathologies in vertebrate intermediate hosts have also been linked with parasitic flatworms. The best examples are probably the teratological limb malformations in North American amphibians, which have been linked with the trematode Ribeiroia on several occasions (Johnson et al., 2001, 2002; Stopper et al., 2002; Johnson and Sutherland, 2003; Johnson and Chase, 2004; Koprivnikar et al., 2012) and could potentially be found in the fossil record (cf. Fröbisch et al., 2014). Nevertheless, limb malformations - including supernumerary limbs and bone bridges - can have various

other causes, meaning their interpretation is not always straightforward (Blaustein and Johnson, 2003; Lunde and Johnson, 2012).

\subsection{Eggs remains in a Pleistocene mammal coprolite}

The oldest Quaternary flatworm evidence is derived from an isolated Middle Pleistocene mammal coprolite (Jouy-Avantin et al., 1999), which these authors attributed to Ursidae based on its morphology and associated fossil finds. The morphology of the eggs (asymmetrical shell, the brown colour and the presence of an operculum) is characteristic of dicrocoelid flatworms, which makes this the oldest direct evidence for the presence of dicrocoelid flatworms (Digenea: Dicrocoelidae). They could not be assigned to a particular genus, although their dimensions are reminiscent of Dicrocoelium and Eurythrema based on egg measurements.

Age: The coprolite (H13 HEN5 1526) derives from an archeological layer at the Caune de l'Arago cave (Tautavel, Pyrénées-Orientales, France) and could be dated to a minimum age of 550,000 years BP (Jouy-Avantin et al., 1999) during a cold and dry climatic period (Lumley et al., 1984).

\subsection{Holocene evidence for parasitic flatworms from ancient remains}

Other Quaternary parasitic flatworm fossils and subfossils derive from the Holocene, mostly from archeological sites (see Gonçalves et al., 2003 for a review, Searcey et al., 2013; Araújo et al., 2014; Beltrame et al., 2014), with possible ages up 6368 years $\mathrm{BP}$ for Trematoda and ages up to 10,000 years BP for Cestoda. They can provide upper constraints for the earliest appearance of various taxa of Cestoda and Trematoda, including genera and species. The age assignment used in archeological publications can be a bit confusing. Before Present (BP) stands for a timescale, which starts at the 1st of January 1950 reflecting the fact that radiocarbon dating became practicable around that time and also antedates large-scale nuclear weapons testing altering the global ratio of carbon isotopes (Taylor, 
1985). Archeological publications often use BC (Before Christ) and AD (Anno Domini). Hundred years BP is 100 years before 1950 (i.e. the year AD 1850). At ages older than about 0.5 Ma, the difference between BP and $\mathrm{AD}$ becomes negligible. We herein use the dates mentioned in the original publications to avoid confusion. Note that age assignment might change or differ according to the dating methods used (Iles, 1980). We recommend using the most conservative age estimates using reliable methods.

Remains of the Cestoda Diphyllobothrium pacificum can be traced back to about 10,000-4000 BP according to Reinhard (1992), although the exact evidence for such an age were not discussed in this paper. The record of anoplocephalid cestodes can be traced back to at least $8920 \pm 200$ years BP based on eggs founds in coprolites attributed to humans (Fugassa et al., 2010). Anoplocephalid remains which could be more specifically determined as Monoecocestus can be found in rodent coprolites dated as old as $6700 \pm 70$ years BP (Sardella et al., 2010). The earliest reports of Hymenolepis were dated approximately from 4000 to 2000 years BC (Gonçalves et al., 2003) and Taenia eggs from an Egyptian mummy attributed to about 3200 years BC (Reyman et al., 1977). According to Gonçalves et al. (2003), trematodes (Fasciola as well as Opisthorchioidea) can be traced back to at least $5400 \pm 40$ to $5230 \pm 40$ years BP (Roever-Bonnet et al., 1979), Dicrocoelium can be traced back to 3384-3370 BC (Dommelier Espejo, 2001), Schistosoma can be traced back to 3200 years BC based on the discovery of Schistosoma haematobium antigen in the shin tissue of an Egyptian predynasty mummy (Deelder et al., 1990) and Schistosoma ova in another contemporary mummy (Reyman et al., 1977), and as Clonorchis sinensis could be traced back to a mummy from Chu Dynasty (475221 years BC) with an age of at least 2171 years BP (Wen-yuan et al., 1984). Eggs of S. haematobium were one of the earliest to be discovered in Egyptian mummies.

Recently, ancient DNA of echinostomatid trematodes was extracted from coprolites of the extinct ratite bird Megalapteryx from New Zealand (Wood et al., 2013), which might range from about 6368 years BP to the $694 \pm 30$ years BP, coincident with the time of their extinction (Wood et al., 2012).

\subsection{Free-living flatworms}

The body fossil record of free-living flatworms is also of little help as it is poorer or even more patchy than the fossil record of parasitic flatworms (Poinar, 2003). The oldest free-living flatworm body fossils derive from 
Eocene Baltic amber (Poinar, 2003) and calcareous nodules of Miocene age (Pierce, 1960; Poinar, 2003), and those of flatworm egg capsules from Quaternary lake sediments (Frey, 1964; Harmsworth, 1968; Gray, 1988). These fossils considerably post-dated divergence time estimates for free-living flatworms derived from molecular clock studies. Older molecular clock studies place the origin of (free-living) Platyhelminthes deep in the Precambrian (Hausdorf, 2000; Otsuka and Sugaya, 2003), but more recent relaxed molecular clock studies place their origins between the latest Precambrian (Ediacaran) and the early Cambrian (Douzery et al., 2004; Peterson et al., 2004, 2008; Erwin et al., 2011). Some Ediacaran fossils have occasionally been related to free-living flatworms (Allison, 1975; Palij et al., 1979; Fedonkin, 1985), although they cannot be confidently assigned to the phylum (Conway Morris, 1981; Labandeira, 2002; Erwin et al., 2011). Even Dickinsonia was assigned to flatworms at one point (Palij et al., 1979; Conway Morris, 1981). The taxonomic position of Dickinsonia has been heavily debated (Retallack, 2007; Brasier and Antcliffe, 2008) and this taxon is often interpreted as one of the earliest divergent metazoans (Xingliang and Reitner, 2006; Sperling and Vinther, 2010). Various Permian to Triassic trace fossils have also been attributed to turbellarians including Polycladida and Tricladida (Alessandrello et al., 1988; Knaust, 2010). The assignment of trace fossils to this phylum is also problematic as various worm-like groups with similar ecology and mode of locomotion could also have produced these traces (Seilacher, 2007). Curvolithus has also been attributed to flatworms (Seilacher, 2007), but could also have been produced by other taxa with similar behaviour (Buatois et al., 1998). Further studies of traces produced by extant forms as well as fossil traces associated with body fossils are therefore important to confidently assign them to the phylum (Collins et al., 2000; Knaust, 2010).

The oldest parasitic flatworm fossils are therefore not only important for putting constraints on free-living flatworms, but also on the presence of Platyzoa in the fossil record, a group currently containing both parasites (Platyhelminthes, Acanthocephala) and free-living taxa (Wey-Fabrizius et al., 2013). The assignment of Cambrian fossils (cambroclaves) to the Acanthocephala as suggested by some authors (Qian and Yin, 1984), which has also been followed in some recent classifications (Amin, 2013), is highly questionable and widely rejected (Conway Morris et al., 1997; Elicki and Wotte, 2003; Kouchinsky et al., 2012). These problematic Cambrian organisms can be classified as Lophotrochozoa at best (Kouchinsky et al., 2012); Compare Conway Morris and Crompton (1982) and Near (2002) for further speculations and hypotheses on the origin and evolution of parasitism towards 
the rise of the Acanthocephala. Furthermore, the oldest accepted record of Rotifera, the free-living relatives of Acanthocephala, derives from Dominican amber deposits (Waggoner and Poinar, 1993), which is now more confidently dated to the Miocene (Iturralde-Vinent and MacPhee, 1996; Iturralde-Vinent, 2001). The oldest confidently assigned Acanthocephala remains have been reported from archeological sites (Gonçalves et al., 2003); some dating back to 9500 years BC according to Fry and Hall (1969). Considering that multiple authors (Upeniece, 2001, 2011; Littlewood and Donovan, 2003) have suggested that the Middle Devonian hook circlets might belong to a platyzoan helminth, a putative reinvestigation of these fossils could be used to constrain the evolutionary history of this entire group. Many studies on extant flatworms have focused on the hook elements of particular groups (Vignon and Sasal, 2010; Vignon, 2011) or taxa (Shinn et al., 2003). Information and illustrations of these helminth structures can also be found in comprehensive systematic treatments: Yamaguti (1959), Schmidt (1986) and Khalil et al. (1994) for Cestoda; Yamaguti (1963a) for Monogenea and Yamaguti (1963b) and Golvan (1969) for Acanthocephala.

\section{INTERPOLATING OR EXTRAPOLATING EXTANT PARASITE-HOST RELATIONSHIPS AND THE ASSUMPTION OF PARASITE-HOST COEVOLUTION}

Analysis of the range of current parasite-host associations has often been used to infer the evolutionary origin of parasitic organisms (Littlewood and Donovan, 2003). With the exception of highly derived taxa, parasitic flatworms do not parasitize hagfishes or lampreys (Littlewood, 2006). This may suggest that parasitic flatworms evolved in basal gnathostomes (Littlewood, 2006), which would lie somewhere around the CambrianOrdovician based on the host fossil record (Friedman and Sallan, 2012; Donoghue and Keating, 2014). This considerably predates the oldest generally accepted fossil evidence for parasitic flatworms, but the fossil record indicates that other groups like pentastomids, which parasitize vertebrates today and might have done in the past, were already around at this time (Walossek and Müller, 1994; Walossek et al., 1994; Maas and Waloszek, 2001; Waloszek et al., 2005; Sanders and Lee, 2010; Castellani et al., 2011). If we map the fossils of parasitic flatworms on their host phylogenies (Figure 4), they are at least consistent with extant parasitic flatworm-host associations, which is not the case for all parasites (Figure 5). Pentastomids mainly parasitize terrestrial vertebrates today (Christoffersen and De Assis, 


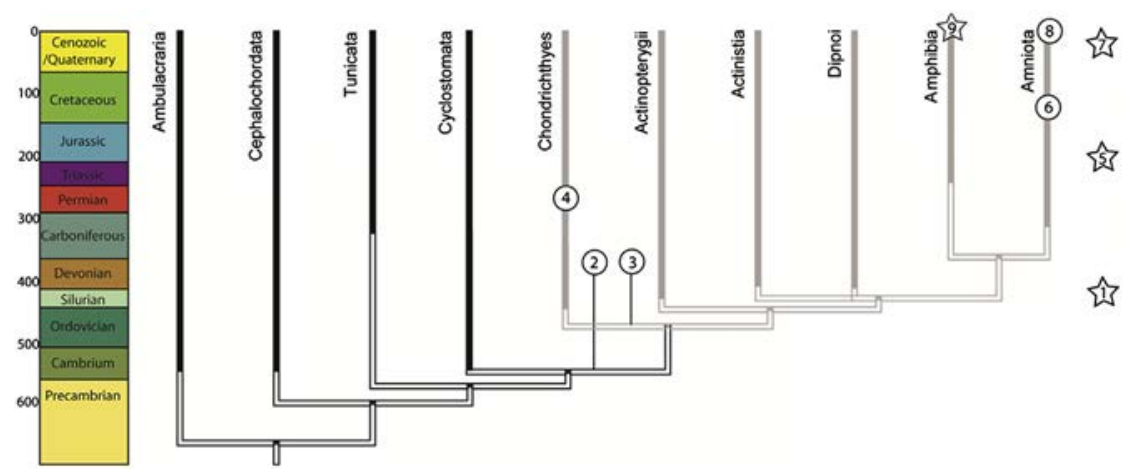

Figure 4 Fossil finds of putative flatworm fossils discussed in the text mapped on their host phylogeny, which was modified from Donoghue and Smith (2003) and Rowe (2004) taking into account new phylogenetic hypotheses summarized in Donoghue and Keating (2014).

2013), but in the Cambrian-Ordovician (Walossek and Müller, 1994; Walossek et al., 1994; Waloszek et al., 2005; Castellani et al., 2011), they are found in marine deposits and there were no terrestrial vertebrates to serve as hosts at this time. Their morphology indicates a parasitic lifestyle, but the

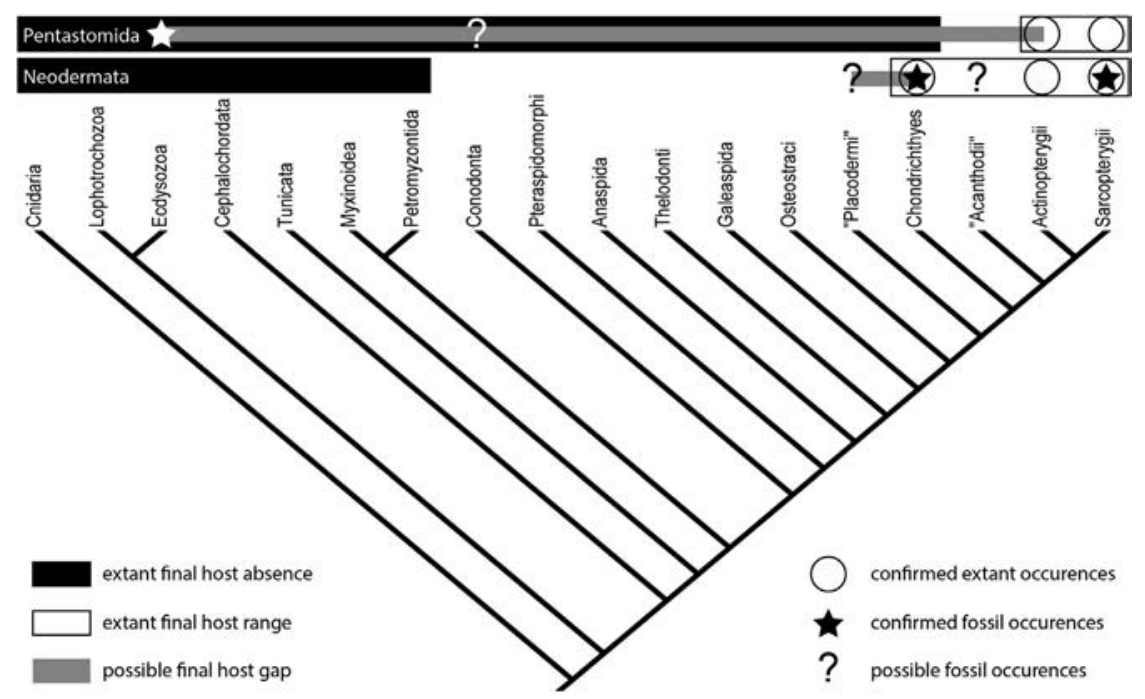

Figure 5 Comparisons of the consistency between extant and fossil host ranges of parasitic flatworms and pentastomids. Host phylogeny was modified from Goudemand et al. (2011). Note that the host gap would be considerably greater if the position of conodonts would be more basal as postulated by some authors (Blieck et al., 2010; Turner et al., 2010). Recent discoveries of Silurian pentastomids associated with ostracods even further extend the host gap between fossil and extant pentastomids (Siveter et al., 2015). 
exact host of these marine forms is still unknown as they were not found directly associated with their hosts. Some have suggested their hosts might have been conodonts (Walossek and Müller, 1994), of which tooth-like remains have been commonly found in these deposits. Interestingly, the Cambrian-Ordovician fossil pentastomids resemble larvae of modern forms that can infest fish, making it conceivable that these small pentastomids represent adults that spent their entire life cycle on small fish-like vertebrates (Sanders and Lee, 2010). The range of the host gap between Cambrian and extant pentastomids (Figure 5) might therefore depend on the systematic position of conodonts, which is still debated. Most authors agree that conodonts are chordates, probably either stem- or crown-vertebrates (Blieck et al., 2010; Turner et al., 2010; Goudemand et al., 2011; Murdock et al., 2013; Donoghue and Keating, 2014). Interestingly, putative pentastomid remains were recently also reported from ostracods within the Silurian Herefordshire Lagerstätte (Siveter et al., 2015), which further increases the host gap between extant and fossil pentastomids. This might suggest that invertebrates might have been the initial hosts in the marine realm, if ostracods are the final hosts as suggested by these authors and if no host switching occurred between the Cambrian and the Silurian. However, pentastomid-host associations from the Cambrian and Ordovician lagerstätten would be necessary to further test this hypothesis.

Thus, it is not always possible to precisely constrain parasite-host associations in the fossil record. This is not only the case for isolated remains of parasites not directly attached to their hosts (Castellani et al., 2011), but also for parasite remains found in isolated coprolites not confidently assignable to precise host taxa (Jouy-Avantin et al., 1999; Poinar and Boucot, 2006; Dentzien-Dias et al., 2013).

Fossils of potential hosts might be common or present in the same layers, although without direct evidence for a parasitic relationship (attached or found within well-preserved body fossils of their hosts), appointing a potential host remains within the realm of speculation. In the case of intermediate hosts, where the fossil evidence is often pathologies or traces, it is hard to be certain of the identity of the culprits since various organisms with similar behaviour can produce similar traces. Furthermore, it might also be hard to identify the final host without finding remains of the putative parasite associated with them. Predator-prey relationships might provide a clue (Ruiz and Lindberg, 1989; De Baets et al., 2011), but direct evidence for predation from one taxon on another is rare in the fossil record too (Brett and Walker, 2002; Walker and Brett, 2002). Nevertheless, age in itself might 
be sufficient to rule out certain hosts if they had not yet evolved, they must have had different intermediate and/or final hosts at that time. Although the hosts of Cambrian-Ordovician pentastomids remain speculative, hosts assignable to taxa they currently parasitize were not around yet, so they must have had additional parasite-host associations in the past which are now extinct.

\section{MOLECULAR CLOCK STUDIES}

Molecular clock (timetree) methods for calibrating phylogenies have the potential to be useful to discriminate evolutionary scenarios in parasite evolution or host-parasite associations (Hypša, 2006). However, molecular clocks still need to be calibrated to obtain absolute age estimates, which is not that straightforward among parasite groups with a patchy fossil record. Thus, a cophylogenetic approach has been used (Hafner et al., 1994; Page et al., 1998; Light and Hafner, 2007), which may in turn provide a robust evolutionary timescale for apparent cospeciating symbiotic species when the timescale of the host lineage is (comparably) well constrained (Moran et al., 1993, 1995). Due to the lack of well-preserved specimens in parasitic flatworms, most molecular clock studies have relied on the host fossil record to inform divergence estimates (Verneau et al., 2002, 2009a,b; Olson et al., 2010; Badets et al., 2011; Héritier et al., 2015). More rarely biogeography (focusing on vicariance events) has been invoked to constrain molecular clock estimates of parasitic flatworms (Zietara and Lumme, 2002; Waltari et al., 2007; Badets et al., 2011; Martínez-Aquino et al., 2014). Only one study (Perkins, 2010) used the parasitic flatworm fossil record as a calibration, although it relied on the Upper Devonian and Carboniferous putative flatworm fossils, whose taxonomic assignment to Monogenea and Cestoda, respectively, is still debated (as discussed above). Other studies have relied on molecular substitution rates derived from other studies (Despres et al., 1992; Zietara et al., 2002; Huyse and Volckaert, 2005), which is even more problematic (Papadopoulou et al., 2010; Hipsley and Müller, 2014).

The best practice for using fossils for molecular clock calibration has been discussed and reviewed extensively (Donoghue and Benton, 2007; Benton et al., 2009; Parham et al., 2012). Most authors agree that the fossil speci-

mens can only directly provide a well-justified minimum constraint for the origin of some particular lineages. According to Parham et al. (2012), 
fossil calibrations are well justified if the following criteria are fulfilled: (1) listing of museum numbers of specimen(s) that demonstrate all the relevant characters and provenance data, (2) availability of apomorphy-based diagnoses of the specimen(s) or an explicit, up-to-data, phylogenetic analysis that includes the specimen(s), (3) explicit statements on the reconciliation of morphological and molecular data sets, (4) specification of the locality and stratigraphic level (to the best current knowledge) from which the calibrating fossils are derived, (5) reference to a published radioisotopic age and/or numeric timescale with details on its selection. Divergence time estimation is not possible with minimum constraints alone, as the substitution rate is variable and unknown; therefore, at least one point calibration or maximum constraint is required to calculate the substitution rate and absolute divergence times (Warnock et al., 2012).

It would therefore be more appropriate to use the oldest estimate (95\% confidence maximum) for the origin of the total group from a robust molecular clock analysis as the maximum, and the oldest fossil assignable with confidence to the crown group (as the minimum), to constrain the evolutionary history of the host (and the parasite). For example, if the origin of parasitic flatworms occurred during the early evolution of gnathostomes as suggested by Littlewood (2006), this would mean they originated between the Cambrian (643 Ma: oldest confidence intervals of Erwin et al., 2011 for this node) and the earliest well-dated fossils that can be confidently assigned to crown-group gnathostomes deriving from Ordovician ( 421.8 Ma: Benton et al., 2009; Donoghue and Keating, 2014). Alternatively, the entire 95\% confidence posterior interval (from robust molecular clock studies) for diverging host clades could be used as priors on the clade ages in the parasites.

A more conservative and less circular approach would be to use the latest robust relaxed molecular clock estimates for the origin of their freeliving ancestors (744 Ma: oldest confidence of Erwin et al., 2011 for this node) and the earliest certain appearance of parasitic flatworms in the fossil record, which would be only Permian ( $>259.4 \mathrm{Ma}$ as discussed above). This would yield quite large confidence intervals (cf. Warnock et al., 2012 for Parasitiformes), but such estimates would be more honest and accurate (closer to reality) than seemingly precise estimates which are arguably inaccurate, since the origin of parasitism falls outside the calibration interval a priori (Warnock et al., 2011). Furthermore, reinvestigation of putative flatworm trace or body fossils from Upper Silurian (>427.7 Ma) or Middle Devonian (>381.9 Ma) deposits might further narrow this 
time interval in the future. The fossil record also provides constraints on the origin of Cestoda in shark hosts (Dentzien-Dias et al., 2013) and Trematoda in archosaur hosts (Poinar and Boucot, 2006). Furthermore, the fossil record provides upper constraints on the origin of Gymnophallidae in the form of characteristic pathologies, dicrocoelid flatworms derived from eggs in coprolites as well as several genera and even species from archeological sites (e.g. Dicrocoelium, Diphyllobothrium, Fasciola, Monoecocestus, Schistosoma, Taenia).

The oldest fossil evidence for schistosomes are antigens deriving from a 3200 BC Egyptian mummy, but the origin of this group is believed to be considerably older based on the evolutionary history of their intermediate or final hosts (Lawton et al., 2011). Davis (1993) suggested that the genus Schistosoma arose before the breakup of the supercontinent Gondwana over $150 \mathrm{Ma}$ based on the distribution of their snail hosts and that ancestors of Asian schistosomes were carried to Asia via India after it separated from Africa. More recent studies (Snyder and Loker, 2000) have suggested a younger, ancestral Asian origin somewhere in the Miocene, which might indicate that schistosomes only colonized Africa around 15-20 Ma (Lawton et al., 2011). Performing a robust molecular clock analysis using dates of fossil Schistosoma and their hosts might be a more formal way to test these hypotheses. In some cases, additional historical dates might become available to constrain certain nodes such as the possible slave transport of Schistosoma mansoni to South America (Lockyer et al., 2003b), which is so far not contradicted by finds of older remains of S. mansoni in archeological sites of South America (Gonçalves et al., 2003). Direct dating of samples yielding ancient DNA (Wood et al., 2013) might also provide additional constraints in such studies. However, a recent study by Mello et al. (2014) has demonstrated that the assignment of calibration information to deeper phylogenetic nodes is more effective in obtaining more precise and accurate divergence time estimates compared to analyses involving calibration at the shallowest node.

Most authors agree that multiple, well-justified calibrations are the best approach to obtain the most robust and accurate molecular clock estimates (Warnock et al., 2011; Parham et al., 2012). Note that careful a priori selection of suitable calibration points cannot be replaced by using as a posteriori cross-validation procedures (Near et al., 2005; Andújar et al., 2014) as these only verify consistency (Clarke et al., 2011). In some cases, multiple inaccurate calibrations might be consistent, which can result in erroneous rejection of more reasonable calibrations. Furthermore, consistent calibrations may be 
redundant by definition, since they fail to correct for changes in rate variation (Clarke et al., 2011; Warnock et al., 2015). Furthermore, calibration should be implemented in the most conservative way, which might result in less precise, but ultimately more accurate divergence estimates (Warnock et al., 2012).

In the absence of a suitable fossil record, one could resort to the use of biogeographic events or calibrations related only to the host fossil record. Nevertheless, both methods also have their problems and add an additional component of circularity to calibration procedures depending on the hypotheses being tested (Hipsley and Müller, 2014). Biogeographic calibrations as they are currently implemented are problematic (Goswami and Upchurch, 2010; Kodandaramaiah, 2011; De Baets and Donoghue, 2012; Hipsley and Müller, 2014), and they should be implemented more conservatively. It should be established when a certain barrier, causal to a given speciation event, actually occurred (De Baets and Donoghue, 2012; Warnock, 2014).

Most importantly, there remains an assumption that biogeographic distributions have not changed significantly in geological time, making it harder to establish whether biogeographic barriers were coincident with speciation events, and introduce an aspects of circularity (Crisp et al., 2011). Having taxon-area relationships consistent or inconsistent with biogeographic events, does not necessarily mean that these clades diversified at the same time as these events, because older events might have led to similar distributions (pseudo-congruence) or younger events might have altered their distributions (pseudo-incongruence; see Donoghue and Moore, 2003). Even for some of the classical examples of groups with current distributions congruent with vicariance, such as onychophorans and cichlids, studies have demonstrated that divergence might predate (Murienne et al., 2014) or postdate (Friedman et al., 2013) the continental break-up of supercontinents, respectively.

Using the fossil record of hosts also introduces an aspect of circularity in addition to other considerations related with fossil calibrations (Donoghue and Benton, 2007; Parham et al., 2012) as discussed above. It assumes that the current parasite-host associations did not markedly change through geological time, which is not necessarily true, particularly in groups which are estimated to range several hundred million years into the past (e.g. the pentastomid example we discussed above). Using hosts also leads to circular reasoning when employing them to investigate hypotheses of parasite-host coevolution. In highly host-specific lineages with simple life cycles like the 
Polystomatidae (Figure 6), it might work well, but for groups with common host switches and/or complex life cycles this approach might be less suitable. The most conservative way to implement them would be to use the oldest reliable estimate for the origin of this group as a maximum and the oldest from well-attributable fossil to this lineage as a minimum. Polystomatid flatworms are one of the most host-specific groups of parasitic flatworms and their direct life cycle that involves a short free-living aquatic larval stage (which means they are probably only passively disseminated by their hosts), have made them an ideal model to test the use of constraints from biogeography and the host fossil record (Bentz et al., 2001, 2006; Verneau et al., 2002, 2009a,b; Badets et al., 2011). Verneau et al. (2002) used 425 Ma to calibrate the split between Actinopterygii and Sarcopterygii (Figure 6), although this event must have happened at the latest by about $419 \mathrm{Ma}$ (Zhu et al., 2009). However, it would be more conservative to use the oldest robust estimate from relaxed molecular clock studies for the separation of actinopterygian from sarcopterygians and the earliest fossil confidently assigned to either tetrapods or lungfishes to constrain this node (Badets et al., 2011). The oldest stem-group lungfish is generally considered to be Diabolepis (Friedman, 2007; Qiao and Zhu, 2009), while one of the oldest ingroup lungfishes might be Westollrhynchus (Qiao and Zhu, 2009). Badets et al. (2011) also suggested that some dates might be consistent with the break-up of the supercontinent Gondwana, although this needs to be further tested with additional sampling.

Taxon sampling can play a large role in tree reconstruction and interpretation with respect to biogeography (Trewick and Gibb, 2010) or host switching (Hafner and Page, 1995). In the case of lineages or parasitehost associations, which have been around for many hundreds of millions of years, host range changes and extinction might contribute significantly to missing taxa, making it hard to infer past biogeographical distribution or parasite-host associations, from extant data alone. There is at least some evidence that extinction might also have played a role in parasitic flatworms and other helminths over longer timescales as several parasite-host associations documented in the (sub)fossil record are now evidently extinct (Upeniece, 2001, 2011; Poinar and Boucot, 2006; Wood et al., 2013). Furthermore, molecular studies with greater taxonomic coverage have particularly focused on biomedically or economically important taxa such as Schistosomatidae (Lockyer et al., 2003b; Orélis-Ribeiro et al., 2014) or particular lineages with a high host specificity such as Polystomatidae (Bentz et al., 2001, 2006; Badets et al., 2011, 2013; Héritier et al., 2015). To better 


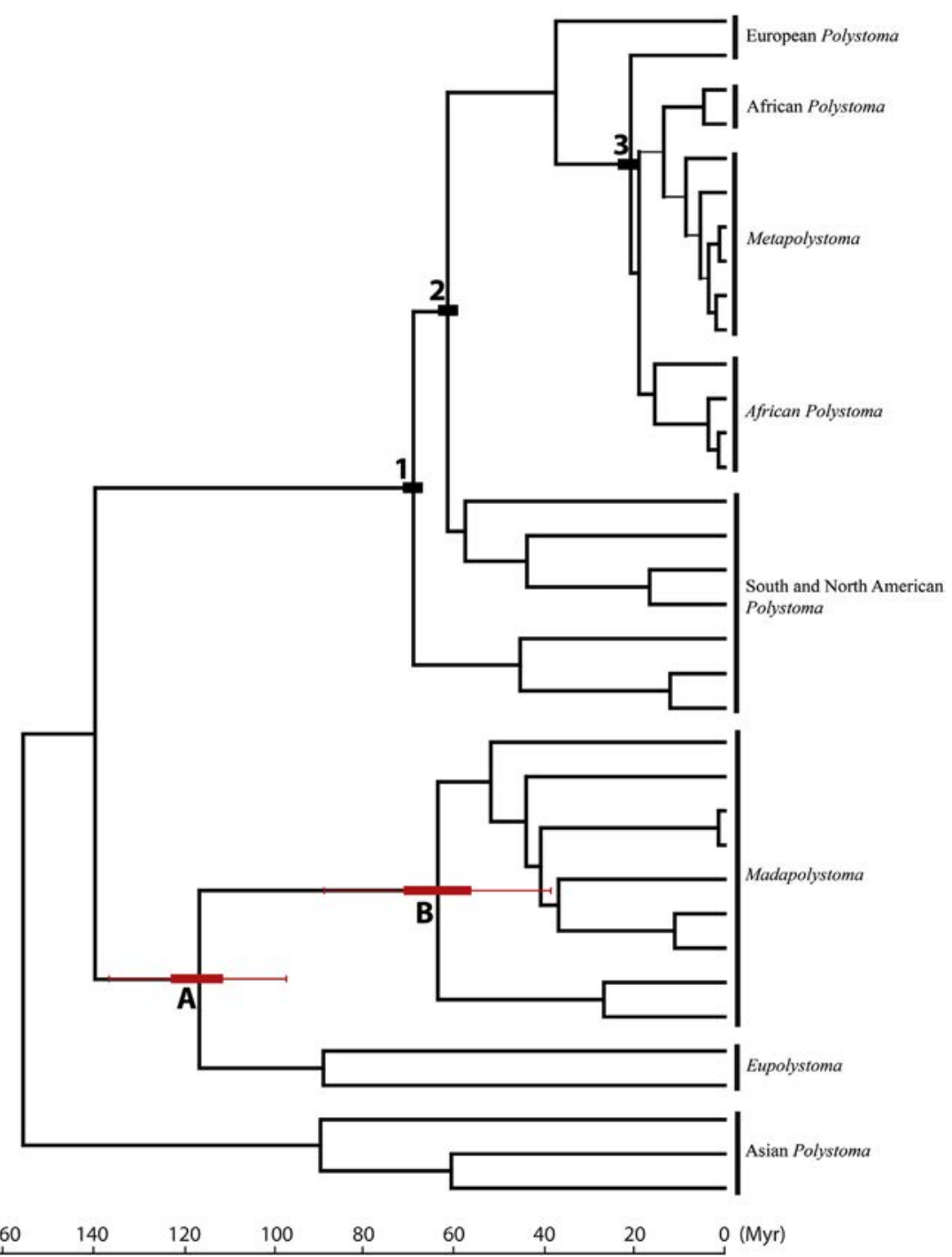

Figure 6 Ultrametric tree of neobatrachian polystomes inferred from MULTIDIVTIME (Modified after Verneau et al. (2009b).). Calibration points (black rectangles, nodes 1-3) were deduced from historical biogeographical scenarios suggested by Bentz et al. (2001, 2006) and Badets et al. (2011). The divergence of the lineage associating Metapolystoma, Eurasian and African Polystoma from their closest South and North American relatives (nodes 1 and 2) was constrained between 65 and $56 \mathrm{Myr}$, reflecting vertebrate exchanges between the two Americas in the Paleocene (Gayet et al., 1992) and possible dispersal to Eurasia via Beringia. The divergence between the European Polystoma species (i.e. Polystoma gallieni) and the lineage grouping Metapolystoma and African Polystoma was constrained between 25 and $5 \mathrm{Myr}$, reflecting the 
understand the evolutionary history using molecular methods, it is essential to sample as many distinct lineages of parasites as possible as well as their freeliving relatives, focusing particularly on evolutionary important taxa which have putative fossil records (e.g. Gymnophallidae, basal Monogenea, Cestoda) or reliable geological constraints derived from biogeography or the evolutionary history of their hosts.

When no appropriate constraints are available, relative rates of uncalibrated molecular clocks can be used to test the support or reject the temporal congruence of parallel distributions or parasite-host evolution (Loader et al., 2007; Hibbett and Matheny, 2009; Loss-Oliveira et al., 2012). Nevertheless, it should be kept in mind when interpreting the results that the rate of molecular evolution might be significantly different between parasites and hosts (Page et al., 1998) or within and between lineages of parasites and/ or hosts (Thomas et al., 2006, 2010; Bromham, 2009), which can bias the results of such studies (Hipsley and Müller, 2014). Furthermore, novel probabilistic approaches make it possible to incorporate in biogeographic inference, estimates of the divergence time of lineages as well as external sources of evidence such as climate, geography, their fossil record or ecological tolerance (Sanmartín, 2012).

\section{CONCLUSIONS AND FUTURE PROSPECTS}

The earliest fossil evidence for the presence of helminths falls in the Middle Devonian in the form of hooks, some of which are most reminiscent of extant Monogenea, although some could also belong to Acanthocephala or more derived flatworms (Cestoda). The oldest secure record of parasitic flatworms with complex parasite life cycles lies in the Permian which can be confidently assigned to cestodes, although the presence of

hypothesized ages of dispersal routes between Eurasia and Africa (Rage, 1988; Bentz et al., 2001). Finally, the root prior was set at $160 \mathrm{Ma}$ (sd $\pm 5 \mathrm{Myr}$ ), corresponding to an initial divergence separating Asian and Australian polystomes from all other neobatrachian polystomes (Badets et al., 2011), hypothetically corresponding to a separation of the western and eastern components of Gondwanaland. Divergence time estimates (see Verneau et al., 2009b) are reported for two nodes that are relevant for understanding the origin of the new Malagasy genus, i.e. Madapolystoma (see Du Preez et al., 2010). According to Verneau et al. (2009b), Madapolystoma would have diverged from Eupolystoma about $116 \mathrm{Ma}$ (node A) and the first crown divergence in Madapolystoma (node B) would have occurred about $63 \mathrm{Ma}$. 
igloo-shaped concretions reminiscent of those caused by gymnophallid trematodes in extant bivalves might already indicate the presence of derived parasitic flatworms with complex parasite life cycles in the Late Silurian $(>428 \mathrm{Ma}$ ). These Silurian occurrences are, however, not consistent with evolutionary history of current gymnophallid hosts (shorebirds), which are believed to have appeared somewhere between the Cretaceous and Eocene. Characteristic pits in bivalves shells indicative for the presence of digenetic trematodes (Gymnophallidae) appear already in the Eocene (Ruiz and Lindberg, 1989; Todd and Harper, 2011; Huntley and De Baets, 2015), which is more or less consistent with the presence of their final host in the fossil record. The first evidence for terrestrial parasitic flatworms and trematodes was found in the form of eggs within a Lower Cretaceous coprolite (Poinar and Boucot, 2006), which can be confidently attributed to archosaurs (potentially theropod dinosaurs or crocodylians). The earliest evidence for dicroelid trematodes (Jouy-Avantin et al., 1999) falls at about $0.55 \mathrm{Ma}$ in the Middle Pleistocene. Various extant genera and species have been described from younger archeological sites (Gonçalves et al., 2003; Araújo et al., 2014). Several putative flatworm fossils need additional study to confidently assign them to a certain lineage of flatworms including platyzoan helminth hooks in Middle Devonian gnathostomes, putative cestode eggs in a Carboniferous shark coprolite and eggs in a Cretaceous archosaur coprolite. Remarkably, the fossil record of parasitic flatworms in considerably better than that of free-living flatworms (Poinar, 2003) and Platyzoa in general (Conway Morris and Crompton, 1982; WeyFabrizius et al., 2013) and it could therefore be used to constrain the evolutionary origin of flatworms and other Platyzoa. Only rarely have studies been performed to assess the evolution of these structures over larger scales; e.g. see Malmberg (1990) for Monogenea, which is a rather controversial study for different reasons (Gusev, 1992). A comparative analysis of hook elements of acanthocephalans and parasitic flatworms (Monogenea, Cestoda) in a new molecular phylogenetic framework would therefore be in order to more confidently assign the fossil hook circlets to a certain clade or phylum. Furthermore, the study of eggs as well as hook circlets, which is now largely done with destructive methods and in two dimensions, would benefit from CT-scanning technologies to characterize their 3Dmorphology and structure in a nondestructive way and potentially reveal additional details or fossils which otherwise might be destroyed by the sample preparation process (e.g. thin-sectioning, chemical sample preparation, resedimentation procedures). 
Fossil evidence can only provide minimum time constraints and is not available for all lineages of parasitic flatworms. Interpolations based on parasite-host associations or biogeographic events can potentially be used to supplement fossil constraints. However, circularity in testing hypotheses should be avoided and caution should be taken when multiple host-switching events are suspected. Before using such calibrations it should be at least verified if this hypothesis is robust to a wider sampling of extant and extinct taxa as well as the evolutionary history of their hosts, where the sampling and fossil record might be comparatively better. We therefore advise implementing such calibrations in the most conservative way. For calibrations based on the evolutionary history of parasites or their hosts, this would correspond with using the oldest estimate based on relaxed molecular clock estimates as maximum and the oldest wellattributable fossils of the parasite or its host as a minimum; for calibrations based on biogeographic events, this would correspond to the using the oldest age of the oldest geological event that could have influenced the distribution of the parasites and their hosts as a maximum and the youngest age of the geological events that could have influenced their distribution as a minimum.

Several recent discoveries indicate that exceptionally preserved gnathostomes or their coprolites might yield additional finds of parasitic flatworm fossils, particularly their attachment organs or their eggs (Littlewood and Donovan, 2003; Poinar and Boucot, 2006; Dentzien-Dias et al., 2013), which can be characteristic for certain lineages. Novel methods like experimental decay studies or computer tomography might provide additional insights into the phylogeny, 3D-morphology and ecology of such fossils. The future of constraining the evolutionary history of Platyzoa and parasitic flatworms lies in molecular clock methodology by combining information from the geological record (particularly body fossils or eggs) and molecular sequences with the fewest assumptions. Characteristic pathologies might also put constraints on the evolutionary history of parasitic flatworm, although this still needs to be further studied in extant and fossil hosts to establish a robust relationship with a particular lineage of parasites (Campbell, 1985; Ituarte et al., 2001, 2005).

\section{ACKNOWLEDGEMENTS}

Michael Calner (Lund University), Ervīns Lukševičs (University of Latvia, Riga), Steve Rosscoe (Hardin-Simmons University), Pascal Godefroit (Royal Belgian Institute of Natural Sciences, Brussels) and Jon Todd (Natural History Museum, London) are thanked for pointing us to literature with the latest stratigraphic assignment of the Silurian, Upper Devonian, Carboniferous, Cretaceous and Eocene flatworm fossils, respectively. Jon Todd (Natural 
History Museum, London) and Cristian Ituarte (Museo Argentino de Ciencias Naturales, Buenos Aires) kindly put pictures of bivalve pathologies linked to trematode parasites at our disposal. This research was partially funded by an SNF grant (2012-141438) to Kenneth De Baets. Rodney Bray (Natural History Museum, London, retired), John Huntley (University of Missouri, Columbia), Tim Littlewood (Natural History Museum, London) and Rachel Warnock (Smithsonian National Museum of Natural History, Washington) kindly read and commented on previous versions of this manuscript.

\section{REFERENCES}

Alessandrello, A., Pinna, G., Teruzzi, G., 1988. Land planarian locomotion trail from the Lower Permian of Lombardian Pre-Alps (Tricladida Terricola). Atti Soc. Ital. Sci. Nat. Mus. Civ. Stor. Nat. Milano 129.

Allison, C.W., 1975. Primitive fossil flatworm from Alaska: new evidence bearing on ancestry of the Metazoa. Geology 3, 649-652.

Amin, O.M., 2013. Classification of the acanthocephala. Folia Parasitol. 60, 273-305.

Andújar, C., Soria-Carrasco, V., Serrano, J., Gómez-Zurita, J., 2014. Congruence test of molecular clock calibration hypotheses based on Bayes factor comparisons. Methods Ecol. Evol. 5, 226-242.

Araújo, A., Reinhard, K., Fernando Ferreira, L., 2015. Paleoparasitology - human parasites in ancient material. Adv. Parasitol. 90, in press.

Badets, M., Preez, L.D., Verneau, O., 2013. Alternative development in Polystoma gallieni (Platyhelminthes, Monogenea) and life cycle evolution. Exp. Parasitol. 135, 283-286.

Badets, M., Whittington, I., Lalubin, F., Allienne, J.F., Maspimby, J.L., Bentz, S., Du Preez, L.H., Barton, D., Hasegawa, H., Tandon, V., Imkongwapang, R., Ohler, A., Combes, C., Verneau, O., 2011. Correlating early evolution of parasitic platyhelminths to Gondwana breakup. Syst. Biol. 60, 762-781.

Baele, J.-M., Godefroit, P., Spagna, P., Dupuis, C., 2012. Geological model and cyclic mass mortality scenarios for the Lower Cretaceous Bernissart Iguanodon Bonebeds. In: Godefroit, P. (Ed.), Bernissart Dinosaurs and Early Cretaceous Terrestrial Ecosystems. Indiana University Press, Bloomington.

Baker, A.J., Pereira, S.L., Paton, T.A., 2007. Phylogenetic relationships and divergence times of Charadriiformes genera: multigene evidence for the Cretaceous origin of at least 14 clades of shorebirds. Biol. Lett. 3, 205-210.

Becker, R.T., Gradstein, F.M., Hammer, O., 2012. Chapter 22-The Devonian Period. In: Gradstein, F.M., Ogg, J.G., Schmitz, M.D., Ogg, G.M. (Eds.), The Geologic Time Scale. Elsevier, Boston.

Beltrame, M.O., Vieira De Souza, M., Araújo, A., Sardella, N.H., 2014. Review of the rodent paleoparasitological knowledge from South America. Quat. Int. 352, 68-74.

Benton, M.J., Donoghue, P.C.J., Asher, R.J., 2009. Calibrating and constraining molecular clocks. In: Hedges, B.S., Kumar, S. (Eds.), The Timetree of Life. Oxford University Press, Oxford.

Bentz, S., Leroy, S., Du Preez, L., Mariaux, J., Vaucher, C., Verneau, O., 2001. Origin and evolution of African Polystoma (Monogenea: Polystomatidae) assessed by molecular methods. Int. J. Parasitol. 31, 697-705.

Bentz, S., Sinnappah-Kang, N.D., Lim, L.-H.S., Lebedev, B., Combes, C., Verneau, O., 2006. Historical biogeography of amphibian parasites, genus Polystoma (Monogenea: Polystomatidae). J. Biogeogr. 33, 742-749.

Berggren, W.A., Aubry, M.-P., 1996. A late Paleocene-early Eocene NW European and North Sea magnetobiochronological correlation network. Geol. Soc. Lond. Spec. Publ. 101, 309-352. 
Bertelli, S., Lindow, B.E.K., Dyke, G.J., Chiappe, L.M., 2010. A well-preserved 'charadriiform-like' fossil bird from the Early Eocene Fur Formation of Denmark. Palaeontology 53, 507-531.

Bertelli, S., Lindow, B.E.K., Dyke, G.J., Mayr, G., 2013. Another charadriiform-like bird from the lower Eocene of Denmark. Paleontol. J. 47, 1282-1301.

Bertrand, C.-E., 1903. Les Coprolithes de Bernissart, Première Partie: Les Coprolithes qui ont été attributés aux Iguanodons. Mém. Mus. R. His. Nat. Belg. 1, 1-154.

Blaustein, A.R., Johnson, P.T.J., 2003. The complexity of deformed amphibians. Front. Ecol. Environ. 1, 87-94.

Blieck, A., Turner, S., Burrow, C.J., Schultze, H.-P., Rexroad, C.B., Bultynck, P., Nowlan, G.S., 2010. Fossils, histology, and phylogeny: why conodonts are not vertebrates. Episodes-Newsmagazine Int. Union Geol. Sci. 33, 234.

Boeger, W., Kritsky, D., 1993. Phylogeny and a revised classification of the Monogenoidea Bychowsky, 1937 (Platyhelminthes). Syst. Parasitol. 26, 1-32.

Boeger, W.A., Kritsky, D.C., 1997. Coevolution of the Monogenoidea (Platyhelminthes) based on a revised hypothesis of parasite phylogeny. Int. J. Parasitol. 27, 1495-1511.

Boeger, W.A., Kritsky, D.C., 2001. Phylogenetic relationships of the Monogenoidea. In: Littlewood, D.T.J., Bray, R.A. (Eds.), Interrelationships of the Platyhelminthes. Taylor \& Francis, London.

Boucot, A.J., 1990. Evolutionary Paleobiology of Behavior and Coevolution. Elsevier, Amsterdam.

Boucot, A.J., Poinar, G.O., 2010. Host-parasite and host-parasitoid relationships and disease. In: Boucot, A.J., Poinar, G.O. (Eds.), Fossil Behavior Compendium. CRC Press.

Bourlat, S.J., Nielsen, C., Lockyer, A.E., Littlewood, D.T.J., Telford, M.J., 2003. Xenoturbella is a deuterostome that eats molluscs. Nature 424, 925-928.

Brasier, M.D., Antcliffe, J.B., 2008. Dickinsonia from Ediacara: a new look at morphology and body construction. Palaeogeogr. Palaeoclimatol. Palaeoecol. 270, 311-323.

Brett, C.E., Walker, S.E., 2002. Predators and predation in Paleozoic marine environments. Paleontol. Soc. Pap. 8, 93-118.

Bromham, L., 2009. Why do species vary in their rate of molecular evolution? Biol. Lett. 5, 401-404.

Brooks, D.R., 1989. The phylogeny of the cercomeria (Platyhelminthes: Rhabdocoela) and general evolutionary principles. J. Parasitol. 75, 606-616.

Brooks, D.R., Mclennan, D.A., 1993. Parascript: Parasites and the Language of Evolution. Smithsonian Institution Press, Washington.

Buatois, L.A., Mangano, M.G., Mikuláš, R., Maples, C.G., 1998. The ichnogenus Curvolithus revisited. J. Paleontol. 72, 758-769.

Bush, A.O., Fernández, J.C., Esch, G.W., Seed, J.R., 2001. Parasitism: The Diversity and Ecology of Animal Parasites. Cambridge University Press.

Bychowsky, B.E., 1937. Ontogenesis and phylogenetic interrelationships of parasitic flatworms. In: News of the Academy of Sciences, USSR Department of Mathematics and Natural Sciences, vol. 4, pp. 1353-1383.

Caira, J.N., Reyda, F.B., 2005. Eucestoda (true tapeworms). In: Rohde, K. (Ed.), Marine Parasitology. CABI Publishing, Oxon.

Calner, M., Jeppsson, L., 2003. Carbonate platform evolution and conodont stratigraphy during the middle Silurian Mulde Event, Gotland, Sweden. Geol. Mag. 140, 173-203.

Campbell, D., 1985. The life cycle of Gymnophallus Rebecqui (Digenea: Gymnophallidae) and the response of the bivalve Abra Tenuis to its metacercariae. J. Mar. Biol. Assoc. U.K. 65, 589-601.

Castellani, C., Maas, A., Waloszek, D., Haug, J.T., 2011. New pentastomids from the Late Cambrian of Sweden - deeper insight of the ontogeny of fossil tongue worms. Palaeontogr. Abt. A 293, 95-145. 
Cavalier-Smith, T., 1998. A revised six-kingdom system of life. Biol. Rev. 73, 203-266.

Chin, K., 2002. Analyses of coprolites produced by carnivorous vertebrates. Paleontol. Soc. Pap. 8, 43-50.

Chin, K., Tokaryk, T.T., Erickson, G.M., Calk, L.C., 1998. A king-sized theropod coprolite. Nature 393, 680-682.

Ching, H.L., 1995. Evaluation of characters of the digenean family Gymnophallidae Morozov, 1955. Can. J. Fish. Aquat. Sci. 52, 78-83.

Christoffersen, M.L., De Assis, J.E., 2013. A systematic monograph of the Recent Pentastomida, with a compilation of their hosts. Zool. Meded. 87, 1-206.

Cisneros, J.C., Abdala, F., Atayman-Güven, S., Rubidge, B.S., Șengör, A.M.C., Schultz, C.L., 2012. Carnivorous dinocephalian from the Middle Permian of Brazil and tetrapod dispersal in Pangaea. Proc. Natl. Acad. Sci. 109, 1584-1588.

Clarke, J.T., Warnock, R.C.M., Donoghue, P.C.J., 2011. Establishing a time-scale for plant evolution. New. Phytol. 192, 266-301.

Collins, A.G., Lipps, J.H., Valentine, J.W., 2000. Modern mucociliary creeping trails and the bodyplans of Neoproterozoic trace-makers. Paleobiology 26, 47-55.

Combes, C., 2001. Parasitism: The Ecology and Evolution of Intimate Interactions. University of Chicago Press.

Conway Morris, S., 1981. Parasites and the fossil record. Parasitology 83, 489-509.

Conway Morris, S., Crampton, J., Bing, X., Chapman, A., 1997. Lower Cambrian cambroclaves (incertae sedis) from Xinjiang, China, with comments on the morphological variability of sclerites. Palaeontology 40, 167-190.

Conway Morris, S., Crompton, D.W.T., 1982. The origins and evolution of Acanthocephala. Biol. Rev. 57, 85-115.

Cramer, B.D., Condon, D.J., Söderlund, U., Marshall, C., Worton, G.J., Thomas, A.T., Calner, M., Ray, D.C., Perrier, V., Boomer, I., Patchett, P.J., Jeppsson, L., 2012. U-Pb (zircon) age constraints on the timing and duration of Wenlock (Silurian) paleocommunity collapse and recovery during the "Big Crisis". Geol. Soc. Am. Bull. 124, 1841-1857.

Cribb, T.H., Bray, R.A., Littlewood, D.T.J., 2001. The nature and evolution of the association among digeneans, molluscs and fishes. Int. J. Parasitol. 31, 997-1011.

Crisp, M.D., Trewick, S.A., Cook, L.G., 2011. Hypothesis testing in biogeography. Trends Ecol. Evol. 26, 66-72.

Davis, G.M., 1993. Evolution of prosobranch snails transmitting Asian Schistosoma; coevolution with Schistosoma: a review. In: Sun, T. (Ed.), Progress in Clinical Parasitology. Springer, New York.

Davydov, V.I., Korn, D., Schmitz, M.D., Gradstein, F.M., Hammer, O., 2012. Chapter 23-The Carboniferous Period. In: Gradstein, F.M., Ogg, J.G., Schmitz, M.D., Ogg, G.M. (Eds.), The Geologic Time Scale. Elsevier, Boston.

De Baets, K., Donoghue, P.C.J., 2012. Molecular clocks and tectonic blocks. Geol. Soc. Am. Abstr. 44, 331.

De Baets, K., Keupp, H., Klug, C., 2015. Parasites of ammonoids. In: Klug, C., Korn, D., De Baets, K., Kruta, I., Mapes, R.H. (Eds.), Ammonoid Paleobiology: From Anatomy to Paleoecology. Springer, The Netherlands.

De Baets, K., Klug, C., Korn, D., 2011. Devonian pearls and ammonoid-endoparasite coevolution. Acta Palaeontol. Pol. 56, 159-180.

De Baets, K., Klug, C., Korn, D., Bartels, C., Poschmann, M., 2013. Emsian Ammonoidea and the age of the Hunsrück Slate (Rhenish Mountains, western Germany). Palaeontogr. A 299, 1-113.

Deelder, A.M., Miller, R.L., De Jonge, N., Krijger, F.W., 1990. Detection of schistosome antigen in mummies. Lancet 335, 724-725.

Dentzien-Dias, P.C., De Figueiredo, A.E.Q., Horn, B., Cisneros, J.C., Schultz, C.L., 2012. Paleobiology of a unique vertebrate coprolites concentration from Rio do Rasto 
formation (Middle/Upper Permian), Paraná Basin, Brazil. J. South Am. Earth Sci. 40, $53-62$.

Dentzien-Dias, P.C., Poinar Jr., G., De Figueiredo, A.E.Q., Pacheco, A.C.L., Horn, B.L.D., Schultz, C.L., 2013. Tapeworm eggs in a 270 million-year-old shark coprolite. PLoS One 8, e55007.

Despres, L., Imbert-Establet, D., Combes, C., Bonhomme, F., 1992. Molecular evidence linking hominid evolution to recent radiation of schistosomes (Platyhelminthes: Trematoda). Mol. Phylogenet. Evol. 1, 295-304.

Dias-Da-Silva, S., 2012. Middle-Late Permian tetrapods from the Rio do Rasto formation, Southern Brazil: a biostratigraphic reassessment. Lethaia 45, 109-120.

Dommelier Espejo, S., 2001. Contribution à l'étude paléoparasitologique des sites néolithiques en environnement lacustre dans les domaines jurassien et péri-alpin (Doctoral dissertation). Université de Reims Champagne-Ardenne.

Donoghue, M.J., Moore, B.R., 2003. Toward an integrative historical biogeography. Integr. Comp. Biol. 43, 261-270.

Donoghue, P.C.J., Benton, M.J., 2007. Rocks and clocks: calibrating the Tree of Life using fossils and molecules. Trends Ecol. Evol. 22, 424-431.

Donoghue, P.C.J., Keating, J.N., 2014. Early vertebrate evolution. Palaeontology 879-893.

Donoghue, P.C.J., Smith, M.P., 2003. The origin and early evolution of chordates: molecular clocks and the fossil record. In: Donoghue, P.C.J., Smith, M.P. (Eds.), Telling the Evolutionary Time: Molecular Clocks and the Fossil Record. CRC Press, London.

Douzery, E.J.P., Snell, E.A., Bapteste, E., Delsuc, F., Philippe, H., 2004. The timing of eukaryotic evolution: Does a relaxed molecular clock reconcile proteins and fossils? Proc. Natl. Acad. Sci. U.S.A. 101, 15386-15391.

Du Preez, L.H., Raharivololoniaina, L., Verneau, O., Vences, M., 2010. A new genus of polystomatid parasitic flatworm (Monogenea: Polystomatidae) without free-swimming life stage from the Malagasy poison frogs. Zootaxa 2722, 54-68.

Dyke, G.J., Van Tuinen, M., 2004. The evolutionary radiation of modern birds (Neornithes): reconciling molecules, morphology and the fossil record. Zool. J. Linn. Soc. 141, 153-177.

Edgecombe, G., Giribet, G., Dunn, C., Hejnol, A., Kristensen, R., Neves, R., Rouse, G., Worsaae, K., Sørensen, M., 2011. Higher-level metazoan relationships: recent progress and remaining questions. Org. Divers. Evol. 11, 151-172.

Egger, B., Lapraz, F., Tomiczek, B., Müller, S., Dessimoz, C., Girstmair, J., Škunca, N., Rawlinson, K.A., Cameron, C.B., Beli, E., 2015. A Transcriptomic-Phylogenomic Analysis of the Evolutionary Relationships of Flatworms. Curr. Biol. 25, 1347-1353.

Elicki, O., Wotte, T., 2003. Cambroclaves from the Cambrian of Sardinia (Italy) and Germany: constraints for the architecture of western Gondwana and the palaeogeographical and palaeoecological potential of cambroclaves. Palaeogeogr. Palaeoclimatol. Palaeoecol. 195, 55-71.

Erwin, D.H., Laflamme, M., Tweedt, S.M., Sperling, E.A., Pisani, D., Peterson, K.J., 2011. The Cambrian conundrum: early divergence and later ecological success in the early history of animals. Science 334, 1091-1097.

Falcon-Lang, H.J., Heckel, P.H., Dimichele, W.A., Blake, B.M., Easterday, C.R., Eble, C.F., Elrick, S., Gastaldo, R.A., Greb, S.F., Martino, R.L., Nelson, W.J., Pfefferkorn, H.W., Phillips, T.L., Rosscoe, S.J., 2011. No major stratigraphic gap exists near the Middle-Upper Pennsylvanian (Desmoinesian-Missourian) boundary in North America. Palaios 26, 125-139.

Fedonkin, M., 1985. Sistematicheskoe opisanie vendskikh Metazoa. In: Sokolov, B.S., Iwanowski, A.B. (Eds.), Vendskaya Sistema 1: Istoriko-geologicheskoe i paleontologicheskoe obosnovanie. Nauka, Moscow.

Frey, D.G., 1964. Remains of animals in quaternary lake and bog sediments and their interpretation. Adv. Limnol. 2, 1-114. 
Friedman, M., 2007. The interrelationships of Devonian lungfishes (Sarcopterygii: Dipnoi) as inferred from neurocranial evidence and new data from the genus Soederberghia Lehman, 1959. Zool. J. Linn. Soc. 151, 115-171.

Friedman, M., Keck, B.P., Dornburg, A., Eytan, R.I., Martin, C.H., Hulsey, C.D., Wainwright, P.C., Near, T.J., 2013. Molecular and fossil evidence place the origin of cichlid fishes long after Gondwanan rifting. Proc. R. Soc. B Biol. Sci. 280.

Friedman, M., Sallan, L.C., 2012. Five hundred million years of extinction and recovery: a phanerozoic survey of large-scale diversity patterns in fishes. Palaeontology 55, 707-742.

Fröbisch, N.B., Bickelmann, C., Witzmann, F., 2014. Early evolution of limb regeneration in tetrapods: evidence from a 300-million-year-old amphibian. Proc. R. Soc. B Biol. Sci. 281.

Fromm, B., Worren, M.M., Hahn, C., Hovig, E., Bachmann, L., 2013. Substantial loss of conserved and gain of novel MicroRNA families in flatworms. Mol. Biol. Evol. 30, 2619-2628.

Fry, G.F., Hall, H., 1969. Parasitological examination of prehistoric human coprolites from Utah. Proc. Utah Acad. Sci. Arts Lett. 46, 102-105.

Fugassa, M.H., Beltrame, M.O., Sardella, N.H., Civalero, M.T., Aschero, C., 2010. Paleoparasitological results from coprolites dated at the Pleistocene-Holocene transition as source of paleoecological evidence in Patagonia. J. Archaeol. Sci. 37, 880-884.

Gayet, M., Rage, J.-C., Sempere, T., Gagnier, P., 1992. Modalités des échanges de vertébrés continentaux entre l'Amérique du nord et l'Amérique du sud au Crétacé supérieur et au Paléocène. Bull. Soc. Géol. Fr. 163, 781-791.

Geyer, G., Hautmann, M., Hagdorn, H., Ockert, W., Streng, M., 2005. Well-preserved mollusks from the Lower Keuper (Ladinian) of Hohenlohe (Southwest Germany). Palaontologische Z. 79, 429-460.

Golvan, Y.J., 1969. Systématique des acanthocéphales (Acanthocephala Rudolphi 1801). Mém. Mus. Natl. Hist. Nat. Sér. A LVII fasc. unique, 1-373.

Gonçalves, M.L.C., Araújo, A., Ferreira, L.F., 2003. Human intestinal parasites in the past: new findings and a review. Mem. Inst. Oswaldo Cruz 98, 103-118.

Goswami, A., Upchurch, P., 2010. The dating game: a reply to Heads (2010). Zool. Scr. 39, 406-409.

Götting, K.-J., 1974. Malakozoologie. Grundriss der Weichtierkunde. Fischer, Stuttgart.

Götting, K.-J., 1979. Durch Parasiten induzierte Perlbildung bei Mytilus edulis L. (Bivalvia). Malacologia 18, 563-567.

Goudemand, N., Orchard, M.J., Urdy, S., Bucher, H., Tafforeau, P., 2011. Synchrotronaided reconstruction of the conodont feeding apparatus and implications for the mouth of the first vertebrates. Proc. Natl. Acad. Sci. 108, 8720-8724.

Gray, J., 1988. Evolution of the freshwater ecosystem: the fossil record. Palaeogeogr. Palaeoclimatol. Palaeoecol. 62, 1-214.

Gusev, A., 1992. A response to Malmberg. Syst. Parasitol. 21, 167-168.

Hafner, M., Sudman, P., Villablanca, F., Spradling, T., Demastes, J., Nadler, S., 1994. Disparate rates of molecular evolution in cospeciating hosts and parasites. Science 265, 1087-1090.

Hafner, M.S., Page, R.D.M., 1995. Molecular phylogenies and host-parasite cospeciation: gophers and lice as a model system. Philos. Trans. R. Soc. Lond. Ser. B Biol. Sci. 349, $77-83$.

Hahn, C., Fromm, B., Bachmann, L., 2014. Comparative genomics of flatworms (Platyhelminthes) reveals shared genomic features of ecto- and endoparastic neodermata. Genome Biol. Evol. 6, 1105-1117.

Harmsworth, R.V., 1968. The developmental history of Blelham Tarn (England) as shown by animal microfossils, with special reference to the Cladocera. Ecol. Monogr. 223-241.

Hausdorf, B., 2000. Early evolution of the bilateria. Syst. Biol. 49, 130-142. 
Hejnol, A., Obst, M., Stamatakis, A., Ott, M., Rouse, G.W., Edgecombe, G.D., Martinez, P., Baguñà, J., Bailly, X., Jondelius, U., Wiens, M., Müller, W.E.G., Seaver, E., Wheeler, W.C., Martindale, M.Q., Giribet, G., Dunn, C.W., 2009. Assessing the root of bilaterian animals with scalable phylogenomic methods. Proc. R. Soc. B 276, 4261-4270.

Henderson, C.M., Davydov, V.I., Wardlaw, B.R., Gradstein, F.M., Hammer, O., 2012. Chapter 24-The Permian Period. In: Gradstein, F.M., Ogg, J.G., Schmitz, M.D., Ogg, G.M. (Eds.), The Geologic Time Scale. Elsevier, Boston.

Héritier, L., Badets, M., Du Preez, L.H., Aisien, M.S.O., Lixian, F., Combes, C., Verneau, O., 2015. Evolutionary processes involved in the diversification of chelonian and mammal polystomatid parasites (Platyhelminthes, Monogenea, Polystomatidae) revealed by palaeoecology of their hosts. Molecular Phylogenetics and Evolution 92, $1-10$.

Hibbett, D., Matheny, P.B., 2009. The relative ages of ectomycorrhizal mushrooms and their plant hosts estimated using Bayesian relaxed molecular clock analyses. BMC Biol. 7, 13.

Hipsley, C.A., Müller, J., 2014. Beyond fossil calibrations: realities of molecular clock practices in evolutionary biology. Fron. Genet. 5.

Hoberg, E., 1999. Systematics of the Eucestoda: advances toward a new phylogenetic paradigm, and observations on the early diversification of tapeworms and vertebrates. Syst. Parasitol. 42, 1-12.

Hoberg, E.P., Jones, A., Bray, R.A., 1999. Phylogenetic analysis among the families of the Cyclophyllidea (Eucestoda) based on comparative morphology, with new hypotheses for co-evolution in vertebrates. Syst. Parasitol. 42, 51-73.

Holz, M., França, A.B., Souza, P.A., Iannuzzi, R., Rohn, R., 2010. A stratigraphic chart of the Late Carboniferous/Permian succession of the eastern border of the Paraná Basin, Brazil, South America. J. South Am. Earth Sci. 29, 381-399.

Hone, D.W.E., Rauhut, O.W.M., 2010. Feeding behaviour and bone utilization by theropod dinosaurs. Lethaia 43, 232-244.

Hunt, A.P., Lucas, S.G., Milàn, J., Spielmann, J.A., 2012. Vertebrate coprolite studies: status and prospectus. N.M. Mus. Nat. Hist. Sci. Bull. 57, 5-24.

Huntley, J.W., 2007. Towards establishing a modern baseline for paleopathology: traceproducing parasites in a bivalve host. J. Shellfish Res. 26, 253-259.

Huntley, J.W., De Baets, K., 2015. Trace fossil evidence of trematode-bivalve parasite-host interactions in deep time. Adv. Parasitol. 90, in press.

Huntley, J.W., Fürsich, F.T., Alberti, M., Hethke, M., Liu, C., 2014. A complete Holocene record of trematode-bivalve infection and implications for the response of parasitism to climate change. Proc. Natl. Acad. Sci. 111, 18150-18155.

Huntley, J.W., Scarponi, D., 2012. Evolutionary and ecological implications of trematode parasitism of modern and fossil northern Adriatic bivalves. Paleobiology 38, 40-51.

Huntley, J.W., Scarponi, D., 2015. Geographic variation of parasitic and predatory traces on mollusks in the northern Adriatic Sea, Italy: implications for the stratigraphic paleobiology of biotic interactions. Paleobiology 41, 134-153.

Huyse, T., Volckaert, F.A.M., 2005. Comparing host and parasite phylogenies: Gyrodactylus flatworms jumping from goby to goby. Syst. Biol. 54, 710-718.

Hypša, V., 2006. Parasite histories and novel phylogenetic tools: alternative approaches to inferring parasite evolution from molecular markers. Int. J. Parasitol. 36, 141-155.

Iles, J.D., 1980. Autopsy of an Egyptian mummy (Nakht-ROM I). Can. Med. Assoc. J. 122, $512-513$.

Ituarte, C., Cremonte, F., Zelaya, D.G., 2005. Parasite-mediated shell alterations in Recent and Holocene sub-Antarctic bivalves: the parasite as modeler of host reaction. Invertebr. Biol. 124, 220-229. 
Ituarte, C.F., Cremonte, F., Deferrari, G., 2001. Mantle-shell complex reactions elicited by digenean metacercariae in Gaimardia trapesina (Bivalvia : Gaimardiidae) from the Southwestern Atlantic Ocean and Magellan Strait. Dis. Aquat. Org. 48, 47-56.

Iturralde-Vinent, M.A., 2001. Geology of the amber-bearing deposits of the greater Antilles. Carribean J. Sci. 37, 141-166.

Iturralde-Vinent, M.A., Macphee, R.D.E., 1996. Age and paleogeographical origin of Dominican amber. Science 273, 1850-1852.

Jeppsson, L., Eriksson, M.E., Calner, M., 2006. A latest Llandovery to latest Ludlow high-resolution biostratigraphy based on the Silurian of Gotland - a summary. GFF 128, 109-114.

Johannessen, O.H., 1973. Deformations of the inner shell surface of Venerupis pullastra (Montagu) (Lamellibranghia) as a result of infection by a trematod metacercaria with a note of Parasitism Leading to Parasitic Castration. Sarsia 52, 117-122.

Johnson, P.T., Lunde, K.B., Haight, R.W., Bowerman, J., Blaustein, A.R., 2001. Ribeiroia ondatrae (Trematoda: Digenea) infection induces severe limb malformations in western toads (Bufo boreas). Can. J. Zool. 79, 370-379.

Johnson, P.T.J., Chase, J.M., 2004. Parasites in the food web: linking amphibian malformations and aquatic eutrophication. Ecol. Lett. 7, 521-526.

Johnson, P.T.J., Lunde, K.B., Thurman, E.M., Ritchie, E.G., Wray, S.N., Sutherland, D.R., Kapfer, J.M., Frest, T.J., Bowerman, J., Blaustein, A.R., 2002. Parasite (Ribeiroia ondatrae) infection linked to amphibian malformations in the western United States. Ecol. Monogr. 72, 151-168.

Johnson, P.T.J., Sutherland, D.R., 2003. Amphibian deformities and Ribeiroia infection: an emerging helminthiasis. Trends Parasitol. 19, 332-335.

Jondelius, U., Ruiz-Trillo, I., Baguñà, J., Riutort, M., 2002. The Nemertodermatida are basal bilaterians and not members of the Platyhelminthes. Zool. Scr. 31, 201-215.

Jouy-Avantin, F., Combes, C., Lumley, H., Miskovsky, J.C., Moné, H., 1999. Helminth eggs in animal coprolites from a Middle Pleistocene site in Europe. J. Parasitol. 85, 376-379.

Jurina, A., Raskatova, M., 2012. New data on the Devonian plant and miospores from the Lode formation, Latvia. Sci. Pap. Univ. Latv. 783, 46-56.

Justine, J.-L., 1998. Non-monophyly of the monogeneans? Int. J. Parasitol. 28, 1653-1657.

Khalil, L.F., Jones, A., Bray, R.A., 1994. Keys to the Cestode Parasites of Vertebrates. CAB International, Wallingford.

Knaust, D., 2010. Remarkably preserved benthic organisms and their traces from a Middle Triassic (Muschelkalk) mud flat. Lethaia 43, 344-356.

Kodandaramaiah, U., 2011. Tectonic calibrations in molecular dating. Curr. Zool. 57, $116-124$.

Koprivnikar, J., Marcogliese, D., Rohr, J., Orlofske, S., Raffel, T., Johnson, P.J., 2012. Macroparasite infections of amphibians: what can they tell us? EcoHealth 9, 342-360.

Kouchinsky, A., Bengtson, S., Runnegar, B., Skovsted, C., Steiner, M., Vendrasco, M., 2012. Chronology of early Cambrian biomineralization. Geol. Mag. 149, 221-251.

Kř́žz, J., 1979. Silurian Cardiolidae (Bivalvia). Sb. Geol. Věd Paleontol. 22, 1-157.

Ksepka, D.T., Ware, J.L., Lamm, K.S., 2014. Flying rocks and flying clocks: disparity in fossil and molecular dates for birds. Proc. R. Soc. B 281, 20140677.

Kutassy, E., 1937. Die älteste fossile Perle und Verletzungsspuren an einem triadischen Megalodus. Math. Naturwiss. Anz. Ung. Akad. Wiss. 55, 1005-1023.

Labandeira, C.C., 2002. Paleobiology of predators, parasitoids, and parsites: death and accomodation in the fossil record of continental invertebrates. Paleontol. Soc. Pap. 8, 211-250.

Lauckner, G., 1983. Diseases of Mollusca: Bivalvia. In: Kinne, O. (Ed.), Diseases of Marine Animals, Volume II: Introduction, Bivalvia to Scaphopoda. Biologische Anstalt Helgoland, Hamburg. 
Laumer, C.E., Giribet, G., 2014. Inclusive taxon sampling suggests a single, stepwise origin of ectolecithality in Platyhelminthes. Biol. J. Linn. Soc. 111, 570-588.

Laumer, C.E., Hejnol, A., Giribet, G., 2015. Nuclear genomic signals of the 'microturbellarian'roots of platyhelminth evolutionary innovation. eLife 4, e05503.

Lawton, S., Hirai, H., Ironside, J., Johnston, D., Rollinson, D., 2011. Genomes and geography: genomic insights into the evolution and phylogeography of the genus Schistosoma. Parasites Vectors 4, 131.

Lee, S.-H., Chai, J.-Y., 2001. A review of Gymnophalloides seoi (Digenea: Gymnophallidae) and human infections in the Republic of Korea. Korean J. Parasitol. 39, 85-118.

Light, J.E., Hafner, M.S., 2007. Cophylogeny and disparate rates of evolution in sympatric lineages of chewing lice on pocket gophers. Mol. Phylogenet. Evol. 45, 997-1013.

Liljedahl, L., 1985. Ecological aspects of a silicified bivalve fauna from the Silurian of Gotland. Lethaia 18, 53-66.

Liljedahl, L., 1994. Silurian nuculoid and modiomorphid bivalves from Sweden. Fossils Strata $33,1-89$.

Littlewood, D.T.J., 2006. The evolution of parasitism in flatworms. In: Maule, A.G., Marks, N.J. (Eds.), Parasitic Flatworms: Molecular Biology, Biochemistry, Immunology and Physiology.

Littlewood, D.T.J., 2008. Platyhelminth systematics and the emergence of new characters. Parasite J. Soc. Fr. Parasitol. 15, 333-341.

Littlewood, D.T.J., Donovan, S.K., 2003. Fossil parasites: a case of identity. Geol. Today 19, 136-142.

Littlewood, D.T.J., Rohde, K., Bray, R.A., Herniou, E.A., 1999a. Phylogeny of the Platyhelminthes and the evolution of parasitism. Biol. J. Linn. Soc. 68, 257-287.

Littlewood, D.T.J., Rohde, K., Clough, K.A., 1999b. The interrelationships of all major groups of Platyhelminthes: phylogenetic evidence from morphology and molecules. Biol. J. Linn. Soc. 66, 75-114.

Littlewood, D.T.J., Waeschenbach, A., 2015. Evolution: A Turn Up for the Worms. Curr. Biol. 25, R457-R460.

Llewellyn, J., 1987. Phylogenetic inference from platyhelminth life-cycle stages. Int. J. Parasitol. 17, 281-289.

Loader, S.P., Pisani, D., Cotton, J.A., Gower, D.J., Day, J.J., Wilkinson, M., 2007. Relative time scales reveal multiple origins of parallel disjunct distributions of African caecilian amphibians. Biol. Lett. 3, 505-508.

Lockyer, A.E., Olson, P.D., Littlewood, D.T.J., 2003a. Utility of complete large and small subunit rRNA genes in resolving the phylogeny of the Neodermata (Platyhelminthes): implications and a review of the cercomer theory. Biol. J. Linn. Soc. 78, $155-171$.

Lockyer, A.E., Olson, P.D., Ostergaard, P., Rollinson, D., Johnston, D.A., Attwood, S.W., Southgate, V.R., Horak, P., Snyder, S.D., Le, T.H., Agatsuma, T., Mcmanus, D.P., Carmichael, A.C., Naem, S., Littlewood, D.T.J., 2003b. The phylogeny of the Schistosomatidae based on three genes with emphasis on the interrelationships of Schistosoma Weinland, 1858. Parasitology 126, 203-224.

Loss-Oliveira, L., Aguiar, B.O., Schrago, C.G., 2012. Testing synchrony in historical biogeography: the case of new world primates and hystricognathi rodents. Evol. Bioinform. 8, 127.

Lukševics, E., Lebedev, O., Mark-Kurik, E., Karatajüte-Talimaa, V., 2009. The earliest evidence of host-parasite interactions in vertebrates. Acta Zool. 90, 335-343.

Lukševičs, E., Stinkulis, G., Mūrnieks, A., Popovs, K., 2012. Geological evolution of the Baltic Artesian Basin. In: Delina, A., Kalvans, A., Saks, T., Bethers, U., Vircavs, V. (Eds.), Highlights of Groundwater Research in the Baltic Artesian Basin. University of Latvia. 
Lukševičs, E., Stinkulis, Ģ., Saks, T., Popovs, K., Jātnieks, J., 2014. The Devonian stratigraphic succession and evolution of the Baltic sedimentary basin. In: Rocha, R., Pais, J., Kullberg, J.C., Finney, S. (Eds.), STRATI 2013. Springer International Publishing.

Lumley, H.D., Fournier, A., Park, Y., Yokoyama, Y., Demouy, A., 1984. Stratigraphie du remplissage Pléistocène moyen de la Caune de l'Arago à Tautavel. Étude de huit carottages effectués de 1981 à 1983. L'Anthropologie 88, 5-18.

Lunde, K.B., Johnson, P.T.J., 2012. A practical guide for the study of malformed amphibians and their causes. J. Herpetol. 46, 429-441.

Maas, A., Waloszek, D., 2001. Cambrian derivatives of the early arthropod stem lineage, pentastomids, tardigrades and lobopodians - an 'Orsten' perspective. Zool. Anz. 240, 451-459.

Malmberg, G., 1990. On the ontogeny of the haptor and the evolution of the Monogenea. Syst. Parasitol. 17, 1-65.

Mark-Kurik, E., Blieck, A., Loboziak, S., Candilier, A.-M., 1999. Miospore assemblage from the Lode Member (Gauja Formation) in Estonia and the Middle-Upper Devonian boundary problem. Proc. Acad. Sci. Est. Geol. 48, 86-98.

Mark-Kurik, E., Põldvere, A., 2012. Devonian stratigraphy in Estonia: current state and problems. Est. J. Earth Sci. 61, 33-47.

Martínez-Aquino, A., Ceccarelli, F.S., Eguiarte, L.E., Vázquez-Domínguez, E., De León, G.P.-P., 2014. Do the historical biogeography and evolutionary history of the digenean Margotrema spp. across central Mexico mirror those of their freshwater fish hosts (Goodeinae)? PLoS One 9, e101700.

Mayr, G., 2011. The phylogeny of charadriiform birds (shorebirds and allies) - reassessing the conflict between morphology and molecules. Zool. J. Linn. Soc. 161, 916-934.

Melchin, M.J., Sadler, P.M., Cramer, B.D., Cooper, R.A., Gradstein, F.M., Hammer, O., 2012. Chapter 21-The Silurian Period. In: Gradstein, F.M., Ogg, J.G., Schmitz, M.D., Ogg, G.M. (Eds.), The Geologic Time Scale. Elsevier, Boston.

Mello, B., Schrago, C.G., Mello, B., Schrago, C.G., 2014. Assignment of calibration information to deeper phylogenetic nodes is more effective in obtaining precise and accurate divergence time estimates. Evol. Bioinform. 10, 79-85.

Mollaret, I., Jamieson, B.G.M., Adlard, R.D., Hugall, A., Lecointre, G., Chombard, C., Justine, J.-L., 1997. Phylogenetic analysis of the Monogenea and their relationships with Digenea and Eucestoda inferred from 28S rDNA sequences. Mol. Biochem. Parasitol. 90, 433-438.

Moran, N.A., Munson, M.A., Baumann, P., Ishikawa, H., 1993. A molecular clock in endosymbiotic bacteria is calibrated using the insect hosts. Proc. R. Soc. Lond. Ser. B Biol. Sci. 253, 167-171.

Moran, N.A., Von Dohlen, C.D., Baumann, P., 1995. Faster evolutionary rates in endosymbiotic bacteria than in cospeciating insect hosts. J. Mol. Evol. 41, 727-731.

Murdock, D.J.E., Dong, X.-P., Repetski, J.E., Marone, F., Stampanoni, M., Donoghue, P.C.J., 2013. The origin of conodonts and of vertebrate mineralized skeletons. Nature 502, 546-549.

Murienne, J., Daniels, S.R., Buckley, T.R., Mayer, G., Giribet, G., 2014. A living fossil tale of Pangaean biogeography. Proc. R. Soc. B Biol. Sci. 281.

Mwinyi, A., Bailly, X., Bourlat, S.J., Jondelius, U., Littlewood, D.T.J., Podsiadlowski, L., 2010. The phylogenetic position of Acoela as revealed by the complete mitochondrial genome of Symsagittifera roscoffensis. BMC Evol. Biol. 10.

Near, T.J., 2002. Acanthocephalan phylogeny and the evolution of parasitism. Integr. Comp. Biol. 42, 668-677.

Near, T.J., Meylan, P.A., Shaffer, H.B., 2005. Assessing concordance of fossil calibration points in molecular clock studies: an example using turtles. Am. Nat. 165, 137-146. 
Ogg, J.G., 2012. Chapter 5-Geomagnetic Polarity Time Scale. The Geologic Time Scale. Elsevier, Boston.

Ogg, J.G., Hinnov, L.A., Huang, C., 2012. Chapter 27-Cretaceous. In: Gradstein, F.M., Ogg, J.G., Schmitz, M.D., Ogg, G.M. (Eds.), The Geologic Time Scale. Elsevier, Boston.

Olson, P.D., Caira, J.N., Jensen, K., Overstreet, R.M., Palm, H.W., Beveridge, I., 2010. Evolution of the trypanorhynch tapeworms: parasite phylogeny supports independent lineages of sharks and rays. Int. J. Parasitol. 40, 223-242.

Olson, P.D., Tkach, V.V., 2005. Advances and trends in the molecular systematics of the parasitic Platyhelminthes. Adv. Parasitol. 60, 165-243.

Orélis-Ribeiro, R., Arias, C.R., Halanych, K.M., Cribb, T.H., Bullard, S.A., 2014. Chapter one - diversity and ancestry of flatworms infecting blood of nontetrapod craniates "fishes". In: Rollinson, D., Stothard, J.R. (Eds.), Advances in Parasitology. Academic Press.

Otsuka, J., Sugaya, N., 2003. Advanced formulation of base pair changes in the stem regions of ribosomal RNAs; its application to mitochondrial rRNAs for resolving the phylogeny of animals. J. Theor. Biol. 222, 447-460.

Page, R.D.M., Lee, P.L.M., Becher, S.A., Griffiths, R., Clayton, D.H., 1998. A different tempo of mitochondrial DNA evolution in birds and their parasitic lice. Mol. Phylogenet. Evol. 9, 276-293.

Palij, V., Posti, E., Fedonkin, M., 1979. Myagkotelye metazoa i iskopaemye sledy zhivotnykh venda i rannego kembriya. Paleontol. Verkhnedokembrijskikh kembrijskikh otlozhenij Vost. Evr. platformy 49-82.

Papadopoulou, A., Anastasiou, I., Vogler, A.P., 2010. Revisiting the insect mitochondrial molecular clock: the mid-Aegean trench calibration. Mol. Biol. Evol. 27, 1659-1672.

Parham, J.F., Donoghue, P.C.J., Bell, C.J., Calway, T.D., Head, J.J., Holroyd, P.A., Inoue, J.G., Irmis, R.B., Joyce, W.G., Ksepka, D.T., Patané, J.S.L., Smith, N.D., Tarver, J.E., Van Tuinen, M., Yang, Z., Angielczyk, K.D., Greenwood, J.M., Hipsley, C.A., Jacobs, L., Makovicky, P.J., Müller, J., Smith, K.T., Theodor, J.M., Warnock, R.C.M., Benton, M.J., 2012. Best practices for justifying fossil calibrations. Syst. Biol. 61, 346-359.

Park, J.K., Kim, K.H., Kang, S., Kim, W., Eom, K.S., Littlewood, D.T.J., 2007. A common origin of complex life cycles in parasitic flatworms: evidence from the complete mitochondrial genome of Microcotyle sebastis (Monogenea : Platyhelminthes). BMC Evol. Biol. 7, 11 .

Paton, T.A., Baker, A.J., Groth, J.G., Barrowclough, G.F., 2003. RAG-1 sequences resolve phylogenetic relationships within Charadriiform birds. Mol. Phylogenet. Evol. 29, $268-278$

Perkins, E., 2010. Family Ties: Molecular Phylogenetics, Evolution and Radiation of Flatworm Parasites (Monogenea: Capsalidae) (Ph.D. thesis), University of Adelaide. https:// digital.library.adelaide.edu.au/dspace/handle/2440/60948.

Perkins, E.M., Donnellan, S.C., Bertozzi, T., Whittington, I.D., 2010. Closing the mitochondrial circle on paraphyly of the Monogenea (Platyhelminthes) infers evolution in the diet of parasitic flatworms. Int. J. Parasitol. 40, 1237-1245.

Peterson, K.J., Cotton, J.A., Gehling, J.G., Pisani, D., 2008. The Ediacaran emergence of bilaterians: congruence between the genetic and the geological fossil records. Phil. Trans. R. Soc. B Biol. Sci. 363, 1435-1443.

Peterson, K.J., Lyons, J.B., Nowak, K.S., Takacs, C.M., Wargo, M.J., Mcpeek, M.A., 2004. Estimating metazoan divergence times with a molecular clock. Proc. Natl. Acad. Sci. U.S.A. 101, 6536-6541.

Petit, G., 2010. Skin nodules in fossil fishes from Monte Bolca (Eocene, Northern Italy). Geodiversitas 32, 157-163.

Petit, G., Khalloufi, B., 2012. Paleopathology of a fossil fish from the Solnhofen Lagerstätte (Upper Jurassic, southern Germany). Int. J. Paleopathol. 2, 42-44. 
Philippe, H., Brinkmann, H., Copley, R.R., Moroz, L.L., Nakano, H., Poustka, A.J., Wallberg, A., Peterson, K.J., Telford, M.J., 2011. Acoelomorph flatworms are deuterostomes related to Xenoturbella. Nature 470, 255-258.

Pierce, W., 1960. Silicified turbellaria from Calico Mountains nodules. Bull. South. Calif. Acad. Sci. 59, 138-143.

Poinar, G., 2003. A rhabdocoel turbellarian (Platyhelminthes, Typhloplanoida) in Baltic amber with a review of fossil and sub-fossil platyhelminths. Invertebr. Biol. 122, 308-312.

Poinar, G., Boucot, A.J., 2006. Evidence of intestinal parasites of dinosaurs. Parasitology 133, 245-249.

Poulin, R., 2005. Evolutionary trends in body size of parasitic flatworms. Biol. J. Linn. Soc. 85, 181-189.

Purnell, M.A., Donoghue, P.C., 2005. Between death and data: biases in interpretation of the fossil record of conodonts. Spec. Pap. Palaeontol. 73, 7-25.

Purnell, M.A., Donoghue, P.C.J., 1997. Architecture and functional morphology of the skeletal apparatus of ozarkodinid conodonts. Phil. Trans. R. Soc. Lond. Ser. B Biol. Sci. 352, $1545-1564$.

Qian, Y., Yin, G., 1984. Zhijinitae and its stratigraphical significance. Acta Palaeontol. Sin. $23,216-223$.

Qiao, T., Zhu, M., 2009. A new tooth-plated lungfish from the Middle Devonian of Yunnan, China, and its phylogenetic relationships. Acta Zool. 90, 236-252.

Rage, J.-C., 1988. Gondwana, Tethys, and terrestrial vertebrates during the Mesozoic and Cainozoic. Geol. Soc. Lond. Spec. Publ. 37, 255-273.

Rakociński, M., 2012. The youngest Devonian record of "Housean pits" in ammonoids. Geol. Q. 56, 387-390.

Reinhard, K.J., 1992. Parasitology as an interpretive tool in archaeology. Am. Antiq. 57, 231-245.

Retallack, G.J., 2007. Growth, decay and burial compaction of Dickinsonia, an iconic Ediacaran fossil. Alcheringa Australas. J. Palaeontol. 31, 215-240.

Reyman, T.A., Zimmerman, M.R., Lewin, P.K., 1977. Autopsy of an Egyptian mummy. 5. Histopathologic investigation. Can. Med. Assoc. J. 117, 470-472.

Roever-Bonnet, H.D., Rijpstra, A., Van Renesse, M., Peen, C., 1979. Helminth eggs and gregarines from coprolites from the excavations at Swifterbant. Swifterbant Contribution 10. Helinium Wetteren 19, 7-12.

Rohde, K., 2005. Amphilinidea (unsegmented tapeworms). In: Rohde, K. (Ed.), Marine Parasitology. CABI Publishing, Oxon.

Rosscoe, S.J., 2008. Idiognathodus and Streptognathodus Species from the Lost Branch to Dewey Sequences (Middle-Upper Pennsylvanian) of the Midcontinent Basin, North America (Doctor of Philosophy). Texas Tech University. https://repositories.tdl.org/ ttu-ir/handle/2346/9102.

Rosscoe, S.J., Barrick, J.E., 2013. North American species of the conodont genus Idiognathodus from the Moscovian-Kasimovian boundary composite sequence and correlation of the Moscovian-Kasimovian stage boundary. N.M. Mus. Nat. Hist. Sci. Bull. 60, 354-371.

Rouse, G.W., 2005. Fossil parasites. In: Rohde, K. (Ed.), Marine Parasitology. CABI Publishing, Oxon.

Rowe, T.B., 2004. Chordate phylogeny and development. In: Donoghue, M.J., Cracraft, J. (Eds.), Assembling the Tree of Life. Oxford University Press, Oxford.

Ruiz-Trillo, I., Riutort, M., Littlewood, D.T.J., Herniou, E.A., Baguna, J., 1999. Acoel flatworms: earliest extant bilaterian metazoans, not members of Platyhelminthes. Science 283, 1919-1923.

Ruiz, G.M., 1991. Consequences of parasitism to marine invertebrates: host evolution? Am. Zool. 31, 831-839. 
Ruiz, G.M., Lindberg, D.R., 1989. A fossil record for trematodes: extent and potential uses. Lethaia 22, 431-438.

Sanders, K.L., Lee, M.S.Y., 2010. Arthropod molecular divergence times and the Cambrian origin of pentastomids. Syst. Biodivers. 8, 63-74.

Sanmartín, I., 2012. Historical biogeography: evolution in time and space. Evol. Educ. Outreach 5, 555-568.

Sardella, N.H., Fugassa, M.H., Rindel, D.D., Goñi, R.A., 2010. Paleoparasitological results for rodent coprolites from Santa Cruz Province, Argentina. Mem. Inst. Oswaldo Cruz 105, 33-40.

Schmidt, G.D., 1986. CRC Handbook of Tapeworm Identification. CRC Press, Boca Raton.

Schnyder, J., Dejax, J., Keppens, E., Nguyen, T.U.,T.T., Spagna, P., Boulila, S., Galbrun, B., Riboulleau, A., Tshibangu, J.-P., Yans, J., 2009. An Early Cretaceous lacustrine record: organic matter and organic carbon isotopes at Bernissart (Mons Basin, Belgium). Palaeogeogr. Palaeoclimatol. Palaeoecol. 281, 79-91.

Searcey, N., Reinhard, K.J., Egarter-Vigl, E., Maixner, F., Piombino-Mascali, D., Zink, A.R., Van Der Sanden, W., Gardner, S.L., Bianucci, R., 2013. Parasitism of the Zweeloo Woman: Dicrocoeliasis evidenced in a Roman period bog mummy. Int. J. Paleopathol. 3, 224-228.

Seilacher, A., 2007. Trace Fossil Analysis. Springer.

Shinn, A.P., Bron, J.E., Sommerville, C., Gibson, D.I., 2003. Comments on the mechanism of attachment in species of the monogenean genus Gyrodactylus. Invertebr. Biol. 122, 1-11.

Siveter, D.J., Briggs, D.E.G., Siveter, D.J., Sutton, M.D., 2015. A 425-million-year-old Silurian pentastomid parasitic on ostracods. Curr. Biol. 25, 1632-1637.

Snyder, S.D., Loker, E.S., 2000. Evolutionary relationships among the Schistosomatidae (Platyhelminthes: Dignea) and an Asian origin for Schistosoma. J. Parasitol. 86, 283-288.

Sperling, E.A., Vinther, J., 2010. A placozoan affinity for Dickinsonia and the evolution of late Proterozoic metazoan feeding modes. Evol. Dev. 12, 201-209.

Stopper, G.F., Hecker, L., Franssen, R.A., Sessions, S.K., 2002. How trematodes cause limb deformities in amphibians. J. Exp. Zool. 294, 252-263.

Struck, T.H., Wey-Fabrizius, A.R., Golombek, A., Hering, L., Weigert, A., Bleidorn, C., Klebow, S., Iakovenko, N., Hausdorf, B., Petersen, M., Kück, P., Herlyn, H., Hankeln, T., 2014. Platyzoan paraphyly based on phylogenomic data supports a noncoelomate ancestry of spiralia. Mol. Biol. Evol. 31, 1833-1849.

Taraschewski, H., 2005. Acanthocephala (thorny or spiny-headed worms). In: Rohde, K. (Ed.), Marine Parasitology. CABI Publishing, Oxon.

Taylor, R.E., 1985. The beginnings of radiocarbon dating in American antiquity: a historical perspective. Am. Antiq. 50, 309-325.

Telford, M.J., Lockyer, A.E., Cartwright-Finch, C., Littlewood, D.T.J., 2003. Combined large and small subunit ribosomal RNA phylogenies support a basal position of the acoelomorph flatworms. Proc. R. Soc. B Biol. Sci. 270, 1077-1083.

Thomas, G., Wills, M., Szekely, T., 2004. A supertree approach to shorebird phylogeny. BMC Evol. Biol. 4, 28.

Thomas, J.A., Welch, J.J., Lanfear, R., Bromham, L., 2010. A generation time effect on the rate of molecular evolution in invertebrates. Mol. Biol. Evol. 27, 1173-1180.

Thomas, J.A., Welch, J.J., Woolfit, M., Bromham, L., 2006. There is no universal molecular clock for invertebrates, but rate variation does not scale with body size. Proc. Natl. Acad. Sci. 103, 7366-7371.

Todd, J.A., Harper, E.M., 2011. Stereotypic boring behaviour inferred from the earliest known octopod feeding traces: Early Eocene, southern England. Lethaia 44, 214-222.

Trewick, S.A., Gibb, G.C., 2010. Vicars, tramps and assembly of the New Zealand avifauna: a review of molecular phylogenetic evidence. Ibis 152, 226-253. 
Turner, S., Burrow, C.J., Schultze, H.-P., Blieck, A., Reif, W.-E., Rexroad, C.B., Bultynck, P., Nowlan, G.S., 2010. False teeth: conodont-vertebrate phylogenetic relationships revisited. Geodiversitas 32, 545-594.

Upeniece, I., 1996. Lodeacanthus gaujicus ng et sp. (Acanthodii: Mesacanthidae) from the Late Devonian of Latvia. Mod. Geol. 20, 383-398.

Upeniece, I., 1998. The first finds of fossil parasitic flatworms (Platyhelminthes). Ichthyolith Issues Spec. Publ. 4, 53-55.

Upeniece, I., 1999. Fossil record of parasitic helminths in fishes. In: 5th International Symposium on Fish Parasites: Abstracts, 154.

Upeniece, I., 2001. The unique fossil assemblage from the Lode Quarry (Upper Devonian, Latvia). Foss. Rec. 4, 101-119.

Upeniece, I., 2011. Palaeoecology and Juvenile Individuals of the Devonian Placoderm and Acanthodian Fishes from Lode Site, Latvia (Unpublished Doctoral thesis). University of Latvia. http://www.lu.lv/zinas/t/7361/

Vandenberghe, N., Hilgen, F.J., Speijer, R.P., Ogg, J.G., Gradstein, F.M., Hammer, O., Hollis, C.J., Hooker, J.J., 2012. Chapter 28-The Paleogene Period. In: Gradstein, F.M., Schmitz, J.G.O.D., Ogg, G.M. (Eds.), The Geologic Time Scale. Elsevier, Boston.

Verneau, O., Bentz, S., Sinnappah, N.D., Preez, L.D., Whittington, I., Combes, C., 2002. A view of early vertebrate evolution inferred from the phylogeny of polystome parasites (Monogenea: Polystomatidae). Proc. R. Soc. B Biol Sci. 269, 535-543.

Verneau, O., Du Preez, L., Badets, M., 2009a. Lessons from parasitic flatworms about evolution and historical biogeography of their vertebrate hosts. C. R. Biol. 332, 149-158.

Verneau, O., Du Preez, L.H., Laurent, V., Raharivololoniaina, L., Glaw, F., Vences, M., 2009b. The double odyssey of Madagascan polystome flatworms leads to new insights on the origins of their amphibian hosts. Proc. Biol. Sci. 276, 1575-1583.

Vignon, M., 2011. Putting in shape - towards a unified approach for the taxonomic description of monogenean haptoral hard parts. Syst. Parasitol. 79, 161-174.

Vignon, M., Sasal, P., 2010. The use of geometric morphometrics in understanding shape variability of sclerotized haptoral structures of monogeneans (Platyhelminthes) with insights into biogeographic variability. Parasitol. Int. 59, 183-191.

Waggoner, B.M., Poinar Jr., G.O., 1993. Fossil habrotrochid rotifers in Dominican amber. Experientia 49, 354-357.

Walker, S.E., Brett, C.E., 2002. Post-Paleozoic patterns in marine predation: was there a Mesozoic and Cenozoic marine predatory revolution? Paleontol. Soc. Pap. 8, 119-194.

Wallberg, A., Curini-Galletti, M., Ahmadzadeh, A., Jondelius, U., 2007. Dismissal of Acoelomorpha: Acoela and Nemertodermatida are separate early bilaterian clades. Zool. Scr. 36, 509-523.

Walossek, D., Müller, K.J., 1994. Pentastomid parasites from the Lower Paleozoic of Sweden. Trans. R. Soc. Edinburgh Earth Sci. 85, 1-37.

Walossek, D., Repetski, J.E., Muller, K.J., 1994. An exceptionally preserved parasitic arthropod, Heymonsicambria taylori n.sp. (Arthropoda incertae sedis: Pentastomida), from Cambrian-Ordovician boundary beds of Newfoundland, Canada. Can. J. Earth Sci. 31, 1664-1671.

Waloszek, D., Repetski, J.E., Maas, A., 2005. A new Late Cambrian pentastomid and a review of the relationships of this parasitic group. Trans. R. Soc. Edinburgh Earth Sci. 96, $163-176$.

Waltari, E., Hoberg, E.P., Lessa, E.P., Cook, J.A., 2007. Eastward Ho: phylogeographical perspectives on colonization of hosts and parasites across the Beringian nexus. J. Biogeogr. 34, 561-574.

Warnock, R., 2014. Molecular clock calibration. In: Rink, W.J., Thompson, J. (Eds.), Encyclopedia of Scientific Dating Methods. Springer, Netherlands. 
Warnock, R.C.M., Parham, J.F., Joyce, W.G., Lyson, T.R., Donoghue, P.C.J., 2015. Calibration uncertainty in molecular dating analyses: there is no substitute for the prior evaluation of time priors. Proc. R. Soc. B Biol Sci. 282.

Warnock, R.C.M., Yang, Z., Donoghue, P.C.J., 2011. Exploring uncertainty in the calibration of the molecular clock. Biol. Lett. 8, 156-159.

Warnock, R.C.M., Yang, Z., Donoghue, P.C.J., 2012. Exploring uncertainty in the calibration of the molecular clock. Biol. Lett. 8, 156-159.

Weber, M., Wey-Fabrizius, A.R., Podsiadlowski, L., Witek, A., Schill, R.O., Sugár, L., Herlyn, H., Hankeln, T., 2013. Phylogenetic analyses of endoparasitic Acanthocephala based on mitochondrial genomes suggest secondary loss of sensory organs. Mol. Phylogenet. Evol. 66, 182-189.

Wen-Yuan, Y., De-Xiang, W., Guang-Fang, S., Zhong-Bi, W., Ren-Sheng, T., 1984. Parasitologische Untersuchung einer alten Leiche aus der Chu-Dynastie der Streitenden Reiche aus dem Mazhuan-Grab Nr. 1, Kreis Jiangling, Provinz Hubei. Acta Acad. Med. Wuhan 4, 23-27.

Wey-Fabrizius, A.R., Podsiadlowski, L., Herlyn, H., Hankeln, T., 2013. Platyzoan mitochondrial genomes. Mol. Phylogenet. Evol. 69, 365-375.

Willems, W.R., Wallberg, A., Jondelius, U., Littlewood, D.T.J., Backeljau, T., Schockaert, E.R., Artois, T.J., 2006. Filling a gap in the phylogeny of flatworms: relationships within the Rhabdocoela (Platyhelminthes), inferred from $18 \mathrm{~S}$ ribosomal DNA sequences. Zool. Scr. 35, 1-17.

Wood, J.R., Wilmshurst, J.M., Rawlence, N.J., Bonner, K.I., Worthy, T.H., Kinsella, J.M., Cooper, A., 2013. A megafauna's microfauna: gastrointestinal parasites of New Zealand's extinct moa (Aves: Dinornithiformes). PLoS One 8, e57315.

Wood, J.R., Wilmshurst, J.M., Wagstaff, S.J., Worthy, T.H., Rawlence, N.J., Cooper, A., 2012. High-resolution coproecology: using coprolites to reconstruct the habits and habitats of New Zealand's extinct upland Moa (Megalapteryx didinus). PLoS One 7, e40025.

Xingliang, Z., Reitner, J., 2006. A fresh look at Dickinsonia: removing it from Vendobionta. Acta Geol. Sin. Engl. Ed. 80, 636-642.

Xylander, W., 2005. Gyrocotylidea (unsegmented tapeworms). In: Xylander, W. (Ed.), Marine Parasitology. CABI Publishing, Oxon.

Yamaguti, S., 1959. Systema Helminthum. In: The Cestodes of Vertebrates, vol. II. Interscience Publishers, New York.

Yamaguti, S., 1963a. Systema Helminthum. In: Monogenea and Aspidocotylea, vol. IV. Interscience Publishers, New Work.

Yamaguti, S., 1963b. Systema Helminthum. In: Acanthocephala, vol. V. Interscience Publishers, New York.

Yans, J., Dejax, J., Pons, D., Dupuis, C., Taquet, P., 2005. Implications paléontologiques et géodynamiques de la datation palynologique des sédiments à faciès wealdien de Bernissart (bassin de Mons, Belgique). C. R. Palevol 4, 135-150.

Yans, J., Dejax, J., Schnyder, J., 2012. On the age of the Bernissart Iguanodons. In: Godefroit, P. (Ed.), Bernissart Dinosaurs and Early Cretaceous Terrestrial Ecosystems.

Zangerl, R., Case, G.R., 1976. Cobelodus aculeatus (Cope), an anacanthous shark from Pennsylvanian black shales of North America. Palaeontogr. Abt. A 154, 107-157.

Zhu, M., Zhao, W., Jia, L., Lu, J., Qiao, T., Qu, Q., 2009. The oldest articulated osteichthyan reveals mosaic gnathostome characters. Nature 458, 469-474.

Zietara, M., Huyse, T., Lumme, J., Volckaert, F., 2002. Deep divergence among subgenera of Gyrodactylus inferred from rDNA ITS region. Parasitology 124, 39-52.

Zietara, M.S., Lumme, J., 2002. Speciation by host switch and adaptive radiation in a fish parasite genus Gyrodactylus (Monogenea, Gyrodactylidae). Evolution 56, 2445-2458. 